OPEN ACCESS

Edited by:

Luregn J. Schlapbach,

The University of Queensland,

Australia

Reviewed by:

John R. Teijaro,

The Scripps Research Institute,

United States

Paul Fisch,

Universitätsklinikum Freiburg,

Germany

*Correspondence:

Gu-Lung Lin

gu-lung.lin@paediatrics.ox.ac.uk

Joseph P. McGinley

joseph.mcginley@paediatrics.ox.ac.uk

tThese authors have contributed equally to this work

Specialty section: This article was submitted to

Viral Immunology,

a section of the journa

Frontiers in Immunology

Received: 10 May 2018

Accepted: 30 August 2018

Published: 27 September 2018

Citation:

Lin G-L, McGinley JP, Drysdale SB and Pollard AJ (2018) Epidemiology and Immune Pathogenesis of Viral Sepsis. Front. Immunol. 9:2147. doi: 10.3389/fimmu.2018.02147

\section{Epidemiology and Immune Pathogenesis of Viral Sepsis}

\author{
Gu-Lung Lin ${ }^{1,2 * t}$, Joseph P. McGinley ${ }^{1,2 *}$, Simon B. Drysdale ${ }^{1,2,3}$ and Andrew J. Pollard ${ }^{1,2}$ \\ ${ }^{1}$ Oxford Vaccine Group, Department of Paediatrics, University of Oxford, Oxford, United Kingdom, ${ }^{2}$ National Institute for \\ Health Research, Oxford Biomedical Research Centre, Oxford, United Kingdom, ${ }^{3}$ Department of Paediatrics, St George's \\ University Hospitals NHS Foundation Trust, London, United Kingdom
}

Sepsis is a life-threatening organ dysfunction caused by a dysregulated host response to infection. Sepsis can be caused by a broad range of pathogens; however, bacterial infections represent the majority of sepsis cases. Up to $42 \%$ of sepsis presentations are culture negative, suggesting a non-bacterial cause. Despite this, diagnosis of viral sepsis remains very rare. Almost any virus can cause sepsis in vulnerable patients (e.g., neonates, infants, and other immunosuppressed groups). The prevalence of viral sepsis is not known, nor is there enough information to make an accurate estimate. The initial standard of care for all cases of sepsis, even those that are subsequently proven to be culture negative, is the immediate use of broad-spectrum antibiotics. In the absence of definite diagnostic criteria for viral sepsis, or at least to exclude bacterial sepsis, this inevitably leads to unnecessary antimicrobial use, with associated consequences for antimicrobial resistance, effects on the host microbiome and excess healthcare costs. It is important to understand non-bacterial causes of sepsis so that inappropriate treatment can be minimised, and appropriate treatments can be developed to improve outcomes. In this review, we summarise what is known about viral sepsis, its most common causes, and how the immune responses to severe viral infections can contribute to sepsis. We also discuss strategies to improve our understanding of viral sepsis, and ways we can integrate this new information into effective treatment.

Keywords: viral sepsis, epidemiology, immune pathogenesis, herpes simplex virus, human enterovirus, human parechovirus, influenza virus, dengue virus

\section{DEFINITION AND EPIDEMIOLOGY OF VIRAL SEPSIS}

\section{Definition of Viral Sepsis}

Sepsis is a complex syndrome of physiological and pathological abnormalities resulting from infection (1). The pathophysiology of sepsis is not fully understood, making it difficult to give an unambiguous and comprehensive definition of sepsis. The Third International Consensus Definitions Task Force (1) advocated a new definition of sepsis and septic shock in 2015. Sepsis should be defined as "life-threatening organ dysfunction caused by a dysregulated host response to infection," whereas septic shock is defined as "a subset of sepsis in which particularly profound circulatory, cellular, and metabolic abnormalities are associated with a greater risk of mortality than with sepsis alone." This version of the definition is designated as "Sepsis-3," while the previous versions are "Sepsis-1" and "Sepsis-2," proposed in 1991 (2) and 2001 (3), respectively. 
The main differences between Sepsis-3 and previous versions are that Sepsis-3 eliminated the terms sepsis syndrome and severe sepsis, and introduced a new definition of sepsis, which is more comparable to the older definition of severe sepsis. In addition, the systemic inflammatory response syndrome (SIRS) criteria, which were the essential elements of Sepsis-1 and Sepsis2 , are no longer used to define sepsis, but they still play a role in the recognition of infection and warrant early intervention for possible sepsis $(1,4)$. Sepsis-3 provides a more specific and universal definition for sepsis, which would improve clinical management and facilitate epidemiological surveys. It also has better predictive ability for in-hospital mortality (1).

However, Sepsis-3 is not designed for paediatric populations, which carry a high burden of sepsis (5). The current, widelyused consensus definition of paediatric sepsis, proposed in 2005, was still built on the SIRS criteria (6). It has been shown to lack specificity and perform poorly in identifying children at high risk of mortality from infection (7-9). In addition, its feasibility and applicability when applying to a non-intensive care setting or low- and middle-income countries remain questionable (9). Some evidence has suggested it may be useful to apply the Sepsis-3 definition to paediatric populations $(8,10-12)$. However, many children with severe viral respiratory tract infections (e.g., bronchiolitis) fulfil the criteria for viral sepsis, but generally clinicians would not regard them as "septic," highlighting the difficulty in providing a robust definition of viral sepsis (13). Therefore, there is an urgent need to convene a consensus task force and design a paediatric definition $(9,14)$.

Although bacterial or fungal infections are commonly attributed as the cause of sepsis, sepsis is infrequently attributed to viral infections. In some cases, viral sepsis is regarded as virus-induced direct tissue or cell damage (e.g., influenza virus-induced pulmonary epithelial damage) instead of systemic dysregulation caused by virus. However, the abovementioned consensus definitions of sepsis, either for adult (1) or paediatric (6) populations are not pathogen-specific, so the same definitions should also apply to viral infection. Therefore, in this review article, viral sepsis is defined as life-threatening organ dysfunction due to a dysregulated host response to viral infection in both adult and paediatric populations. Viral infection can be diagnosed by associated clinical presentations plus positive results of culture, antigen detection, molecular detection (e.g., polymerase chain reaction, PCR), serology, histopathology or immunohistochemistry (15). Viral sepsis should always be considered in septic patients lacking evidence of bacterial, parasitic or fungal infection, and laboratory tests for viruses should be arranged accordingly. In the following sections, we will review the current evidence available about the epidemiology, aetiology, immune pathogenesis, and potential treatments of viral sepsis.

\section{Burden of Viral Sepsis}

Most of the available large-scale epidemiological studies on sepsis were based on the Sepsis-2 criteria. Severe sepsis defined by Sepsis-2 (3) is similar to the definition of sepsis according to the Sepsis-3 criteria (1). Therefore, where available, we will use the data on severe sepsis from studies based on Sepsis- 2 to represent the epidemiological data on sepsis, defined by Sepsis-3.

In general, the incidence and severity of sepsis are climbing over time, whereas sepsis-associated mortality is declining (1619). A recent systematic review and meta-analysis (17) reported that the global incidence and mortality of hospital-treated sepsis in adult populations were 270 per 100,000 person-years and $26 \%$, respectively, in the last decade. Extrapolating these figures translated to global estimates of 19.4 million sepsis cases and 5.3 million deaths annually. Another global study (5) found that the incidence and mortality of sepsis in paediatric populations (between 4 weeks and 20 years of age) were 22 per 100,000 person-years and 9-20\%, respectively; the incidence and mortality of neonatal sepsis (Sepsis-2 definition) were 2,202 per 100,000 live births and 11-19\%, respectively. Extrapolation of the data resulted in global estimates of 3 million sepsis episodes in neonates and 1.2 million episodes in paediatric populations annually. Infection-related mortality outside the neonatal period has been falling, but these sepsis episode rates emphasise the importance of focus on tackling sepsis in the first 4 weeks of life.

Both studies $(5,17)$ indicated several limitations about the epidemiological surveys on sepsis. Firstly, there was no population-level data available from low-income countries, which represent $87 \%$ of the world's population (17) and bear a huge burden of infectious diseases and sepsis (20). Therefore, these figures were likely to be underestimates. Secondly, the lack of a universal and specific sepsis definition and severity criteria leads to substantial heterogeneity in case definitions among studies. Lastly, studies may use different denominators to calculate the incidence and mortality (e.g., person-years, specified populations, live births). These hurdles make meta-analysis more challenging and susceptible to bias.

On top of these limitations, most epidemiological studies on sepsis either excluded cases of viral origin or did not specify the proportion of viral sepsis. Organisms that contribute to sepsis can be identified in 59-69\% of septic patients (i.e., documented sepsis), with bacteria usually accounting for more than $70 \%$ of the documented sepsis cases (21-23). Viruses only contribute $\sim 1 \%$ of the documented sepsis cases in some studies $(22,23)$. However, this figure likely understates the prevalence of viral sepsis for several reasons. A recent Southeast Asian prospective study (24), using a predefined set of laboratory tests (including PCR tests for multiple viruses), demonstrated that viruses accounted for 76 and $33 \%$ of the documented sepsis cases (Sepsis-2 definition) in paediatric (excluding neonates) and adult populations, respectively. The most common viruses identified were dengue viruses (27\%), followed by rhinovirus (23\%), influenza viruses (14\%), and respiratory syncytial virus (12\%). Although the study was only conducted in tropical middleincome countries and not using the Sepsis-3 definition, it still provides direct evidence that viral sepsis may be underdiagnosed if diagnostic tests for viruses are not performed.

However, the identified viruses could be the single causative agent of sepsis (e.g., dengue), a contributor to secondary bacterial sepsis (e.g., influenza and staphylococcal sepsis) (25), coinfection of unknown significance (e.g., rhinovirus), prolonged or persistent shedding of a previous infection (e.g., adenovirus) 
(26), an "innocent" latent infection (e.g., Epstein-Barr virus) or a false positive result. This also needs to be taken in the clinical context. For example, a profoundly immunosuppressed child with respiratory symptoms and a high rhinovirus viral load in blood would suggest rhinovirus as the cause of the sepsis. However, a previously well child with purulent meningitis and rhinovirus in a nasal swab would not. This uncertainty is another major obstacle to studying the epidemiology of viral sepsis, particularly in cases where bacterial infection is also documented or the identified virus does not usually cause fulminant disease. What role the identified virus plays in a septic patient is still an area of debate.

Similarly, another prospective study demonstrated that a third of adult patients requiring intensive care for severe pneumonia had viral infections, detected by a predefined array of diagnostic tests (including PCR tests for multiple viruses) (27). Pneumonia is the most common clinical syndrome in patients with sepsis $(21,22,28)$. Moreover, another prospective study found that patients with culture-negative sepsis had significantly lower levels of procalcitonin than those with documented sepsis (21). It has been shown that elevated procalcitonin levels are more likely to be seen in bacterial infections than viral infections and may be used to differentiate infections caused by bacteria and viruses $(29,30)$. Therefore, these studies suggest that viruses may cause more sepsis cases. The exact incidence of viral sepsis remains to be elucidated.

The World Health Organization and the World Health Assembly have listed sepsis as one of the global health priorities for the following years (31). They also recognized the importance of understanding the epidemiological burden of sepsis. In order to obtain a comprehensive picture of the burden of sepsis, there is an urgent need to understand the epidemiology of viral sepsis.

\section{AETIOLOGY OF VIRAL SEPSIS}

Almost any virus can cause viral sepsis in susceptible populations (24). Herpes simplex virus (HSV) and enteroviruses are the most common viral causes of neonatal sepsis (32), while enteroviruses and human parechoviruses (HPeVs) are the most common causes of viral sepsis in young children (33). In addition, influenza viruses are not only a major cause of severe infections and deaths among children younger than 5 years of age, older adults, pregnant women and immunosuppressed individuals (34), but can also lead to substantial morbidity and mortality in older children and adults in other age groups (35). Furthermore, dengue viruses are a leading cause of sepsis in some tropical countries (24). We will review the characteristics and epidemiology of these prominent causes of viral sepsis in the following section.

\section{Herpes Simplex Viruses}

HSV is one of the leading causes of neonatal sepsis (32). In neonates, HSV can cause three types of disease: skin, eye and mouth disease, encephalitis, and disseminated disease (36). Disseminated HSV disease is the most severe form of HSV infection, with a case fatality rate of as high as $29 \%$ (29). Patients with lethargy, severe hepatic dysfunction or delayed treatment have higher mortality (29). HSV can also cause fulminant hepatitis in non-neonatal populations, typically without obvious cholestasis (37). Both disseminated HSV disease and fulminant HSV hepatitis have a clinical presentation of viral sepsis, involving hepatic dysfunction, respiratory failure, disseminated intravascular coagulopathy, and haemodynamic instability (36, 38). In the absence of skin lesions, disseminated HSV disease and HSV hepatitis are difficult to differentiate clinically from sepsis caused by other pathogens $(36,38)$.

Studies have reported various incidence rates of neonatal HSV infection, ranging from 8 to 60 per 100,000 live births, with disseminated HSV disease accounting for $25 \%$ of cases (39). Some viral factors are associated with viral sepsis. Firstly, a large inoculum of HSV may increase the risk of viral sepsis (38). Secondly, it has been shown that maternal genital HSV type 1 (HSV-1) infection has a higher probability of transmission to neonates during labour than HSV type 2 (HSV-2) infection (40). However, HSV-2 accounts for a higher proportion of neonatal central nervous system (CNS) and disseminated HSV diseases although HSV-1 causes about $60 \%$ of cases of neonatal HSV infection (41). This also explains why HSV-2 is associated with higher morbidity and mortality (39). Furthermore, neonates born to mothers with newly-acquired genital HSV infection near term are at greater risk for neonatal HSV infection than those born to mothers with reactivated genital HSV infection (42).

\section{Human Enteroviruses}

Enterovirus is a genus of viruses of the family Picornaviridae, which have been shown to cause sepsis in immunodeficient and paediatric populations (43). Enteroviruses are the causative agents of a broad range of clinical conditions including aseptic meningitis and myocarditis, although many cases are asymptomatic or benign (44). There are about 10-15 million symptomatic enteroviral infections in the United States per year (43) with a disproportionately high number of infections occurring in neonates (11.4-11.6\% compared with the average yearly birth cohort percentage of $1.5 \%)(45,46)$. The enteroviruses that have the highest association with sepsis are coxsackievirus and echovirus (47); these viruses primarily cause sepsis in neonates (47). In contrast, enterovirus A71 can lead to viral sepsis in children beyond the neonatal period $(48,49)$, predominantly in children younger than 2 years of age (50).

Risk factors for neonatal enteroviral infection include exposure to maternal secretions or blood during delivery, maternal infection just before or at delivery, and a lack of previous maternal infection by the infecting serotype, resulting in low maternal antibody levels against that serotype of virus. The majority of severe neonatal enteroviral infections occur between days 3 and 5 of life, suggesting that the acquisition is generally in the perinatal period and is preceded by maternal infection (51).

\section{Human Parechoviruses}

$\mathrm{HPeVs}$ are also frequently associated with sepsis in paediatric and immunodeficient populations. HPeVs have previously been defined as a subset of the genus Enterovirus but were eventually re-classified as their own genus of viruses after sequencing revealed them to be unrelated to enterovirus. Antibodies against 
$\mathrm{HPeVs}$ are present in the cerebrospinal fluid (CSF) of up to 99\% of the population (52), with $\mathrm{HPeV}$ type 3 ( $\mathrm{HPeV} 3$ ) (the most common cause of $\mathrm{HPeV}$ sepsis) being present in $10 \%$ of the population studied in the Netherlands and $13 \%$ in Finland (52). HPeVs are the second most common cause of viral sepsis in young children after enteroviral infections (33). $\mathrm{HPeV}$ infections are often asymptomatic or present with very mild symptoms, although severe infections can have symptoms ranging from sepsis and sepsis-like illnesses to viral meningitis and encephalitis (33). White matter abnormalities on magnetic resonance imaging have been found in cases of $\mathrm{HPeV}$ encephalitis, which may play a role in the development of sequelae (53-55). The development of white matter abnormalities and sequelae seems to show little association with short term outcomes (54). Clinical presentations of $\mathrm{HPeV}$ infections are similar to those of enteroviral infections, are clinically indistinguishable and require serology or PCR to discriminate between them. $\mathrm{HPeV} 3$ is the $\mathrm{HPeV}$ most commonly associated with severe disease, with other $\mathrm{HPeVs}$ known to cause severe disease only rarely $(56,57)$.

Licensed specific antiviral therapy is not available for $\mathrm{HPeV}$ or enterovirus infections, despite their relatively high incidence in neonatal encephalitis and systemic infections (58). This presents a promising target for future research, and a tangible way to reduce the incidence of neonatal viral sepsis and associated infant mortality globally.

The addition of a PCR test for HPeVs to the re-analysis of 761 banked CSF samples from children presenting with sepsis found a $31 \%$ increase in detection of a viral cause of sepsis in these cases (33), with $\mathrm{HPeV}$ being found in $0.4-8.2 \%$ of neonates presenting with sepsis, depending on the year, with an overall detection rate of $4.6 \%$. It is thus likely that viral sepsis caused by HPeVs is frequently underdiagnosed.

\section{Influenza Viruses}

Influenza $A$ and $B$ viruses cause seasonal epidemics and out-of-season outbreaks worldwide (34). Influenza sepsis can present as severe pneumonia, acute respiratory distress syndrome (ARDS), myocarditis or encephalopathy. The estimated annual incidence proportions of influenza virus infection are 5-10\% in adults and $20-30 \%$ in children (34). A modelling study demonstrated that seasonal influenza epidemics account for an estimated 290,000-650,000 respiratory deaths annually, with $10,000-110,000$ occurring among children younger than 5 years of age (59). The true mortality attributable to influenza viruses must be higher because the figures do not include deaths from other causes, such as circulatory deaths (59), which also make up a large proportion of influenza virus-associated deaths (60). Approximately $60 \%$ of mortality from seasonal influenza occurs in people older than 65 years of age (59), while $80 \%$ of the nonsurvivors in the 2009 influenza H1N1 pandemic were people younger than 65 years of age (61). The age shift may be explained by some level of immunity to $\mathrm{H} 1 \mathrm{~N} 1$ strains in people born before 1957, when H1N1 strains widely circulated and had not been replaced by the $\mathrm{H} 2 \mathrm{~N} 2$ pandemic strain (35). In addition, a study (62) found high titres of low-avidity, non-protective immunoglobulin $\mathrm{G}$ against the viral $\mathrm{H} 1$ antigen in severely ill middle-aged adult patients. Pulmonary immune complex deposition and complement activation were also observed. This provides evidence that immune complex-mediated disease may be part of the pathogenesis of severe pneumonia in middle-aged patients, which also contributes to the age shift.

The pathogenesis of influenza virus infection depends on viral virulence and host responses (63). Host responses will be discussed in the next section. The crucial site for influenza virus infection that leads to severe pneumonia is the alveolar epithelium (64). Haemagglutinins (HAs) of different strains of influenza viruses have varied tropism for the airway epithelium. For example, seasonal influenza viruses bind preferentially to the epithelium in the upper airway and bronchi and, to a lesser extent, to the alveolar epithelium $(65,66)$. By contrast, HA of the 2009 pandemic influenza A (H1N1) virus attaches to both type 1 and type 2 pneumocytes, while HA of the avian influenza H5N1 virus primarily binds to type 2 pneumocytes (64). The second determinant of viral virulence is the viral polymerase complex, which is associated with different levels of viral replication and cytokine production in the infected epithelial cells (65). Therefore, the differing tropism, along with the varied degrees of viral replication and cytokine production, induces various extents of cell death and in part explains the differences in pathogenicity between different strains $(63,67)$.

\section{Dengue Viruses}

Dengue is a common viral infection in tropical countries and has the capacity to cause viral sepsis. Dengue viruses are currently considered the most important and widespread virus spread by mosquitos (68). Over $50 \%$ of the world's population live in areas where dengue infection occurs (68). Estimates of yearly dengue infections range from 50 million up to 400 million (68). Dengue viruses are members of the family Flaviviridae, with four distinct serotypes; serotypes 1, 2, 3, and 4 (69). Infection with any of these serotypes gives full protection against that serotype; however, after infection with one serotype, infection with any of the others can result in an enhanced and more severe form of the disease (70). All serotypes of dengue viruses have been implicated in severe dengue (68).

One study in Thailand found that $\sim 14 \%$ of patients diagnosed with sepsis (Sepsis-2 definition) tested positive for dengue viruses upon re-analysis of banked serum samples by PCR (71). Of the patients who were diagnosed with dengue by PCR from banked serum samples five had died, of which four had been diagnosed with sepsis but not dengue infection. It was suggested that it may prove beneficial to increase testing for dengue viruses in patients presenting with sepsis to ensure the patient receives appropriate treatment (71).

Table 1 summarises the clinical syndromes, epidemiology and risk factors of sepsis caused by these viruses and adenovirus. While being the most commonly detected viruses causing sepsis, they are far from the only ones. Other viruses, such as chikungunya virus (84), hantavirus (85), coronaviruses (86), Ebola virus (87), and Lassa virus (88), among many others, are also major contributors to viral sepsis across the globe. Due to the limited data on many of these viruses, the immune responses against them and their pathogenesis are poorly understood. In addition, these viruses do not occur at a high enough incidence in 
TABLE 1 | Summary of the clinical syndromes, epidemiology and risk factors of sepsis caused by different viruses.

\begin{tabular}{|c|c|c|c|c|}
\hline & Clinical syndromes & Epidemiology & Risk factors for sepsis & References \\
\hline HSV & $\begin{array}{l}\text { Disseminated disease } \\
\text { Hepatitis }\end{array}$ & $\begin{array}{l}\text { Neonatal disseminated disease } \\
\text { Incidence: } 2-15 \text { per } 100,000 \text { live births } \\
\text { Mortality: up to } 29 \%\end{array}$ & $\begin{array}{l}\text { Newly-acquired maternal genital infection } \\
\text { near term } \\
\text { HSV-2 infection (compared with HSV-1 } \\
\text { infection) }\end{array}$ & $(29,38,39)$ \\
\hline Enterovirus & $\begin{array}{l}\text { Sepsis-like illness } \\
\text { Myocarditis } \\
\text { Encephalomyelitis } \\
\text { Pulmonary oedema or } \\
\text { haemorrhage }\end{array}$ & $\begin{array}{l}\text { Incidence: } 37 \% \text { of young infants ( }<90 \text { days of } \\
\text { age) with sepsis }{ }^{a} \text { and without signs of localised } \\
\text { infection } \\
\text { Mortality of neonatal enteroviral sepsis: } \\
\text { up to } 42 \%\end{array}$ & $\begin{array}{l}\text { Lack of maternal antibodies } \\
\text { Maternal infection just before or at delivery } \\
\text { Neonatal infection with echovirus } 6,9,11,19 \\
\text { or coxsackievirus B2-B5 } \\
\text { Enterovirus A71 infection in young children }\end{array}$ & $(29,48,72,73)$ \\
\hline $\mathrm{HPeV}$ & $\begin{array}{l}\text { Sepsis-like illness } \\
\text { Meningoencephalitis }\end{array}$ & $\begin{array}{l}\text { Incidence: } 15 \% \text { of young infants ( }<90 \text { days of } \\
\text { age) with sepsis }{ }^{\mathrm{a}} \text { and without signs of localised } \\
\text { infection }\end{array}$ & $\begin{array}{l}\text { HPeV3 infection (compared with infection } \\
\text { with other types of HPeV) }\end{array}$ & $(33,73)$ \\
\hline Influenza virus & $\begin{array}{l}\text { ARDS } \\
\text { Myocarditis } \\
\text { Encephalopathy }\end{array}$ & $\begin{array}{l}\text { Incidence: } 1 \text { million cases of severe respiratory } \\
\text { infections in children }<5 \text { years of age worldwide } \\
\text { annually } \\
\text { Mortality: } 290,000-650,000 \text { respiratory deaths } \\
\text { worldwide annually (all age groups) }\end{array}$ & $\begin{array}{l}\text { People of extreme age ( }<5 \text { or }>65 \text { years) } \\
\text { Immunosuppression } \\
\text { Pregnancy } \\
\text { Influenza A (H3N2) virus infection (compared } \\
\text { with influenza A (H1N1) or B virus infections) }\end{array}$ & $(34,59,74,75)$ \\
\hline Dengue virus & $\begin{array}{l}\text { Severe dengue }{ }^{b} \\
\text { Dengue shock }{ }^{b}\end{array}$ & $\begin{array}{l}\text { Incidence: 58-96 million symptomatic dengue } \\
\text { infections with 250,000-500,000 progressing to } \\
\text { severe disease worldwide annually; } 8 \% \text { of sepsis } \\
\text { cases }^{C} \text { in Southeast Asian } \\
\text { Mortality: 9,000-24,000 deaths worldwide } \\
\text { annually }\end{array}$ & $\begin{array}{l}\text { Previous dengue infection (with a different } \\
\text { serotype) }\end{array}$ & $(20,24,70,76-79)$ \\
\hline Adenovirus & $\begin{array}{l}\text { Disseminated disease } \\
\text { Meningoencephalitis } \\
\text { Severe pneumonia }\end{array}$ & $\begin{array}{l}\text { Disseminated disease in children } \\
\text { Incidence: } 2.5 \% \text { of adenovirus infection } \\
\text { Mortality: } 55 \%\end{array}$ & $\begin{array}{l}\text { Immunosuppression (particularly allogeneic } \\
\text { HSCT) } \\
\text { Young children } \\
\text { Infection with adenovirus serotypes } 3 \text { and } 7\end{array}$ & $(80-83)$ \\
\hline
\end{tabular}

a Sepsis was defined according to age-specific criteria, Rochester criteria and Yale observation scale.

b2009 WHO revised dengue case classification.

'Sepsis was defined by the Sepsis-2 definition.

HSV, herpes simplex virus; HPeV, human parechovirus; ARDS, acute respiratory distress syndrome; HSCT, haematopoietic stem cell transplants.

populations in high-income countries to gain significant research funding. This may change in future as more effective treatments are discovered for more frequently occurring infections and less common diseases become more attractive to research.

\section{SUSCEPTIBLE POPULATIONS}

Neonates and young children (89), pregnant women (90), older adults (89), and immunosuppressed individuals (91) are especially susceptible to severe infections and sepsis. Here, we will review current evidence regarding the immunological characteristics of these susceptible populations that predispose them to severe infections, especially viral sepsis.

\section{Neonates and Young Children}

The immature and naïve immune system of neonates predisposes them to infection with intracellular pathogens and sepsis (92, 93). One of the most remarkable features of the neonatal innate immune system is the bias in favour of type 2 helper $\mathrm{T}\left(\mathrm{T}_{\mathrm{H}} 2\right)$-cell responses, which results in reduced secretion of pro-inflammatory cytokines, such as interleukin (IL)-12, tumour necrosis factor (TNF), interferon (IFN)- $\gamma$, and IL-1 $\beta$, which together with immature innate immunity allows pathogens to replicate and spread more easily $(93,94)$. In contrast, neonatal monocytes and antigen-presenting cells display preserved or even enhanced Toll-like receptor (TLR)-mediated production of some cytokines (e.g., IL-6, IL-10, and IL-23) (93). In addition, studies have shown that neonates can experience highly exaggerated inflammatory responses through some pathways, such as the TLR2 pathway, in response to specific antigens $(95,96)$. These exaggerated responses may play a role in the development of sepsis in response to viral infections.

There are also other features of the neonatal immune system that increase susceptibility to severe viral infection. Firstly, neonatal monocytes have decreased expression of the major histocompatibility complex (MHC) class II, which leads to impaired antigen presentation (93). Secondly, neonatal dendritic cells have a reduced production of TNF and type I IFNs, impaired upregulation of CD80 and CD86 co-stimulatory molecules, and reduced stimulation of $\mathrm{T}$ cell proliferation, all of which can contribute to a decreased ability to clear viruses (93). In addition, neonates have low levels of complement 
components (93); complement is responsible for antibodyindependent opsonization and lysis of pathogens and plays a role in the activation and enhancement of the adaptive immunity against infections (97). Furthermore, there are both quantitative and qualitative defects in neonatal neutrophils (93). For example, lower levels of neutrophils in stress situations, such as sepsis, are seen in neonates. The qualitative deficiencies in neonatal neutrophils include impairment of adhesion, migration, chemotaxis and amplification. These defects lead to a reduced ability to clear viruses and other pathogens. Lastly, the naïve, immature adaptive immunity of neonates, together with the lack of pre-existing immunological memory, increases their susceptibility to various pathogens and severity of infection (94).

It is worth noting that susceptibility to sepsis persists beyond the neonatal period (i.e., 4 weeks of age). Young children also bear a substantial burden of sepsis, with the peak incidence of 516 per 100,000 population in the infant group (Sepsis-2 definition) (5). Likewise, hospitalisation rates for viral infections, such as influenza (98) and respiratory syncytial virus infection (99), are highest in children younger than 2 years of age. In addition, children with underlying diseases (e.g., bronchopulmonary dysplasia, congenital heart diseases, neurological disorders) are at greater risk of developing severe viral infections and sepsis $(98,100,101)$.

\section{Pregnant Women}

Pregnant women are another population at greater risk of viral sepsis than the general population. There have been several reports on maternal sepsis caused by influenza, herpes simplex, varicella-zoster, and chikungunya viruses, among others (102106). Recognition of the problem of influenza related mortality in late pregnancy has led a number of countries to introduce routine influenza vaccination in pregnancy. According to the Global Burden of Disease Study, there were an estimated 17,900 deaths from maternal sepsis and other infections globally in 2015, accounting for $6.5 \%$ of the total deaths from maternal disorders (20). The incidence of maternal sepsis is around 4149 per 100,000 pregnancies with a mortality rate of $1.8-4.5 \%$ in the United Kingdom (105) and the United States (107). An increasing trend in the incidence and mortality of maternal sepsis has been seen in the recent decades (108). However, these studies did not report the proportion of women with viral sepsis.

The maternal immune system is complicated and delicately modulated. It is tolerant to paternal antigens and the "allogeneic" foetus, while efficient at identifying and defending against invading pathogens to protect the mother and the foetus (109). The immunological characteristics during pregnancy depend on the stage of gestation and the area of focus. For example, a proinflammatory [type 1 helper $\mathrm{T}\left(\mathrm{T}_{\mathrm{H}} 1\right)$-biased] status with high levels of IL-6, IL-8, and TNF- $\alpha$ is seen in pregnant women during the first trimester of pregnancy, which is critical for embryo implantation, placentation and initial foetal growth. Following this, pregnant women develop a more anti-inflammatory $\left(\mathrm{T}_{\mathrm{H}} 2\right.$ biased) status with increased levels of prostaglandin $E_{2}$, IL-4, and IL-10 while the foetus grows rapidly. Before labour, the immune system shifts back to a pro-inflammatory $\left(\mathrm{T}_{\mathrm{H}} 1\right.$-biased) status, which helps parturition (110). Additionally, the epithelial cells of the reproductive tract are down-regulated with low levels of IL-1 $\beta$, IL-8, and IL-6 in cervical fluid (109). Pregnant women also encounter reduced levels of immunoglobulin G (111) and a decreased number of helper $\mathrm{T}$ lymphocytes (111) throughout pregnancy.

The maternal immune system is not yet understood completely. However, we do know that it is constantly changing, and not just universally suppressed. The unique immune profiles result in different responses to pathogens, which may make pregnant women more susceptible to some pathogens depending on the stage of pregnancy (110). In addition, the immune response originating from the placenta also influences the maternal immune response to microorganisms. For example, an insult such as a subclinical viral infection of the placenta can affect the maternal immune system and increase the maternal susceptibility to various pathogens, including viruses (112).

\section{Older Adults}

Older adults ( $>60$ years old) are a population at a significantly greater risk of sepsis from all causes than the general population (113). Older adults were found to have an incidence of sepsis of 26.2 cases per 1,000, which is considerably higher than the 3.0 cases per 1,000 observed in the general population (114). There are many reasons for this increased susceptibility, including a higher likelihood of co-morbidities, prolonged hospitalisation times, generally weaker immune responses, and immunosenescence (115). Viral sepsis in older adults presents one of the most serious upcoming global health problems, as the global population of older adults is set to overtake the "young" population by 2050 . It is therefore important to understand the unique conditions within older adults to better facilitate the development of suitable treatments. Many of the factors involved in the increased susceptibility of older adult populations to sepsis also increase the susceptibility to viral infection, and thus viral sepsis.

Comorbidities for sepsis and severe viral infection such as diabetes mellitus (116), renal failure $(117,118)$ chronic obstructive pulmonary disease $(117,119)$, heart conditions $(120)$, and obesity $(120,121)$ are much more prevalent in older adult populations. There are many other comorbidities in older adults that can increase the risk of viral sepsis. These often are associated with immunosuppression [e.g., renal failure (122)].

Immunosenescence is the gradual deterioration of the immune system brought on by advancing age, which increases susceptibility to both viral infections, and the development of viral sepsis. It is characterised by a decrease in the function of phagocytes (123-125), antigen presentation (124) and lymphocytes $(126,127)$, as well as decreased cellular replication $(128,129)$ and ability to respond to cytokine stimulus (130). Older adults also experience persistent $\mathrm{T}$ cell exhaustion in part due to constant low-level inflammation, thought to be caused by accumulation of self-debris brought on by a decrease in the ability to clear them (131). This process, often called "inflammaging" is characterised by elevated baseline levels of the cytokines IL6 , IL-1, and TNF- $\alpha(130,132)$. Another factor contributing to 
$\mathrm{T}$ cell exhaustion in older adults is the prolonged length of inflammatory states after infections (133) which can result in decreased $\mathrm{T}$ cell replication and inhibition of co-stimulation by antigen presenting cells. This results in a decreased ability to effectively respond to infection, allowing viral infections to easily evade eradication by the immune system and develop into serious systemic infections.

\section{Immunosuppressed Individuals}

The number of immunosuppressed hosts has grown considerably over the last decades due to the widespread use of cytoablative chemotherapy, monoclonal antibodies and immunomodulatory agents for neoplastic and autoimmune diseases, the epidemic of human immunodeficiency virus (HIV) and increasing numbers of haematopoietic stem cell transplants (HSCT) and solid organ transplants (SOT). The clinical picture of sepsis in immunosuppressed hosts is usually diminished or non-specific, making it difficult to diagnose or distinguish from other non-infectious causes, such as transplant rejection $(91,134)$. Thus, infection and sepsis continue to be the major cause of morbidity and mortality in immunosuppressed hosts $(91,135)$. A multicentre, prospective study (135) in the United States showed that $42 \%$ of HSCT recipients had viral infections at some point post-transplant (median follow-up, 413 days), and infection accounted for $21 \%$ of deaths. However, the authors did not specify the mortality rate caused by viral infections.

Individuals with neutropenia or taking corticosteroids mainly have impaired innate immunity, while transplant recipients primarily have defects in adaptive immunity $(91,136)$. Similar to immunocompetent hosts, many viruses are able to cause sepsis in immunosuppressed hosts, but some are of particular concern. For example, HSCT and SOT recipients are at high risk of infection with cytomegalovirus (CMV), other herpesviruses and respiratory viruses (e.g., adenovirus, influenza virus, parainfluenza virus and respiratory syncytial virus) (136). In transplant recipients, the timing of viral infections varies according to the types of transplant, antimicrobial prophylaxis received, and other host and donor factors, but they are most likely to occur 1 month after transplantation when defects in cell-mediated immunity dominate or graft-versus-host disease occurs $(134,137)$. By contrast, the risk of infection with CMV, other herpesviruses, and respiratory viruses may be lower in neutropenic hosts, patients with HIV infection and individuals taking corticosteroids than in transplant recipients (136).

Primary immunodeficiency is another special category of diseases comprising at least 200 genetic disorders of variable severity (138) and affecting more than six million people worldwide (139). This population is at substantial risk of disseminated viral infection and sepsis. Young children with inborn errors in signalling pathways upstream of the production of type I IFNs are at higher risk of developing life-threatening viral infection (140). For example, signal transducer and activator of transcription 1 (STAT1) or nuclear factor (NF)- $\kappa$ B essential modulator (NEMO) deficiency leads to lethal HSV disease and various other severe viral infections (140-142). Deficiency in interferon regulatory factor 7 also leads to more severe viral infections due to decreased downstream IFN signalling
(143). Other disorders that have been demonstrated to have an effect in viral infections are the IFITM3 SNP rs12252, which affects CD8+ T cell numbers (144), and variations in receptor components such as the IFIH1 receptor, which decreases downstream signalling to IFNs (145). In addition, patients with severe combined immunodeficiency have major defects in B and T lymphocyte development, facing a substantial risk of infection caused by a wide variety of pathogens (e.g., fulminant adenovirus and HSV infections) $(146,147)$.

\section{THE IMMUNOLOGY OF VIRAL SEPSIS}

\section{Normal Immune Responses to Viral Infection}

Pattern recognition receptors (PRRs) are responsible for the initial detection of viruses (148). They can recognize pathogenassociated molecular patterns (PAMPs) (e.g., viral RNA and DNA) and damage-associated molecular patterns (DAMPs) (e.g., host DNA and proteins) (148). There are several families of PRRs, such as TLRs, cytosolic RNA sensors [e.g., retinoic acid-inducible gene (RIG)-I and melanoma differentiation-associated gene 5 (MDA5)] and cytosolic DNA sensors (e.g., absent in melanoma 2 , IFN- $\gamma$-inducible protein 16 , and cyclic GMP-AMP synthase) (149). When encountering pathogens, PRRs play a critical role in the activation of innate immune responses and the recruitment of leucocytes $(148,149)$.

First of all, the innate responses stimulate the production of pro-inflammatory cytokines and have an immediate antiviral effect on preventing virus spread and replication, which is mainly exerted by type I IFNs (150, 151). Furthermore, PRRs can trigger the development of virus-specific adaptive immunity (e.g., cytotoxic T lymphocytes, antibodies) to clear viruses and virusinfected cells (152). Lastly, PRRs can induce the secretion of anti-inflammatory cytokines such as IL-10 and IL-13, which help to resolve the pro-inflammatory state and promote tissue repair $(149,153,154)$. The normal immune responses to viral infection are summarised in Figure 1A.

\section{Hyper-Inflammatory Phase of Viral Sepsis}

Although pro-inflammatory cytokines are essential to mediate innate immunity, they (particularly IL-6) can cause host damage (149). The release of DAMPs from the damaged tissues and cells can further stimulate PRR signalling and lead to a chain reaction culminating in viral sepsis if the infection is not cleared (155).

\section{Herpes Simplex Viruses}

TLR2 and TLR9 comprise the major PRR signalling pathways activated in response to HSV infection $(96,156)$. Many of the clinical features of viral sepsis caused by HSV can be attributed to exuberant responses induced through TLR signalling (95). It has been demonstrated that levels of IL- 6 are negatively associated with the survival of HSV encephalitis (157). Neonatal cord-blood cells mount higher levels of pro-inflammatory cytokines (IL-6 and IL-8) when challenged with HSV than adult blood cells (95). Therefore, HSV causes a higher ratio of IL- 6 to TNF in neonates, which contributes to severe inflammation and the development of sepsis (93). 


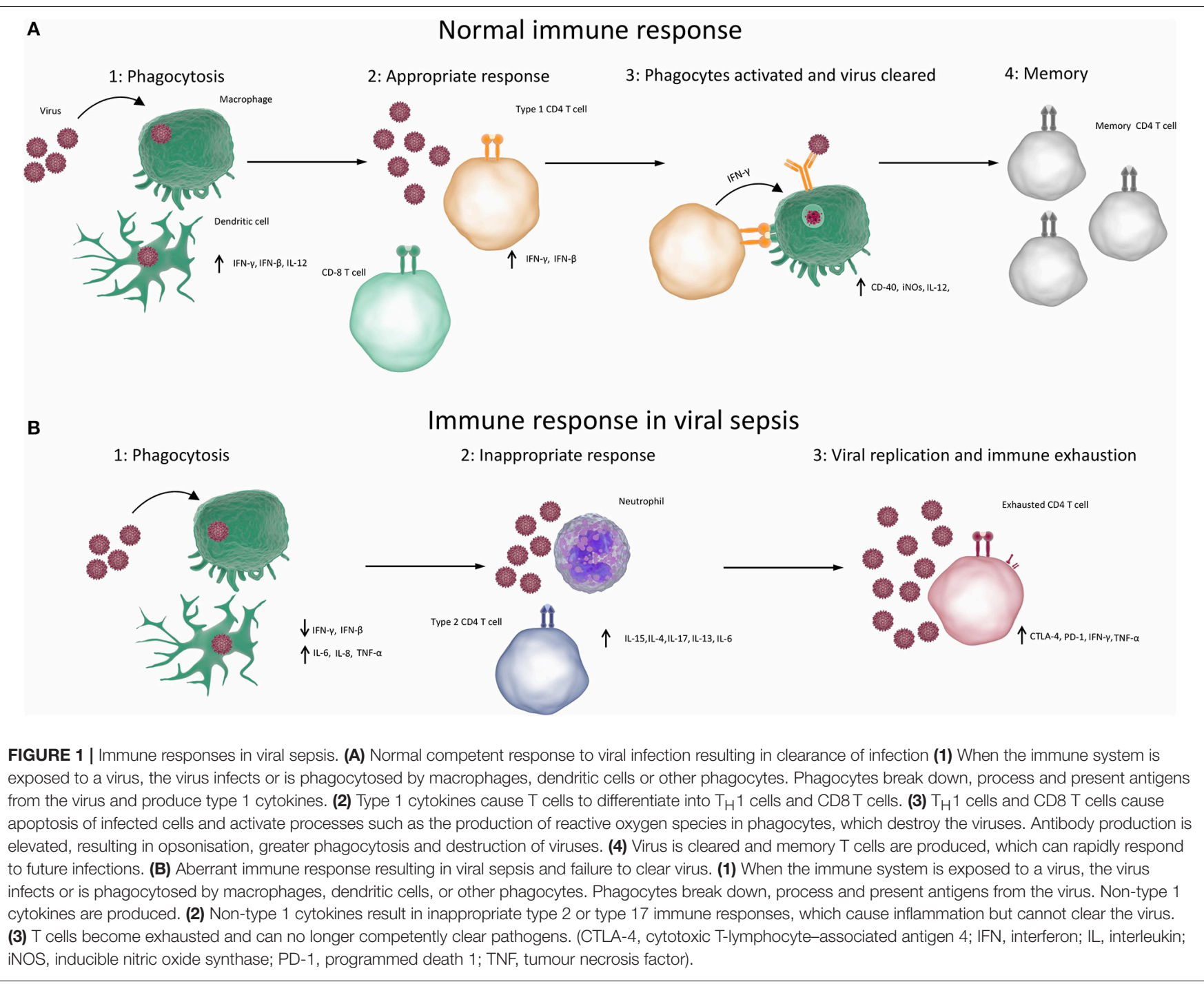

Dysregulated secretion of pro-inflammatory cytokines in response to HSV infection also induces the production of high mobility group box 1 protein (HMGB1) from injured cells (158). HMGB1 is a nuclear protein and regulates DNA transcription. HMGB1 can mount a pro-inflammatory cytokine response to pathological levels and lead to the release of cytochrome $\mathrm{c}$ (158). It has been demonstrated that the peak of HMGB1 comes before the peak of cytochrome $c$ in a clinical case of neonatal disseminated HSV disease (158). Cytochrome c subsequently activates caspase- 3 and caspase-7, resulting in extensive apoptosis (149). Apoptosis is responsible for the development of multiorgan dysfunction in septic patients (159).

\section{Human Enteroviruses}

Human enterovirus infections are characterised by a type I IFN response, induced by PRRs that respond to RNA viruses. Enterovirus detection has been found to primarily involve the TLR and RIG-I-like receptor (RLR) signalling pathways. In particular TLRs 3 (160), 7 (161), 8 (162), and 9 (163) have been implicated in the innate response to enteroviruses. The RLR most commonly associated with enterovirus infection is MDA5. MDA5 is involved in detecting intracellular RNA viruses (164) and has been found to play a small role in the development of the innate immune response to enterovirus infection (165). Although other PRR signalling cascades are likely to have a role in sensing enteroviruses, this role has not yet been characterised. Human enteroviruses employ a diverse range of strategies to evade the immune response and replicate. These strategies are critical to the ability to cause viral sepsis, as they allow the virus to replicate sufficiently to cause significant inflammation. Some broad strategies of immune evasion used by enteroviruses are interference with innate immune signalling by either interfering with or avoiding initial PRR recognition [poliovirus can subvert MDA5 signalling and induce apoptosis of innate immune effector cells (166)] or interfering with the downstream cytokine signalling pathways. There is evidence that enterovirus A71 can interfere with the IFN signalling pathway at several points (167). These immune evasion mechanisms have been shown to have 
a direct impact on survival in mouse models, with blockage of type I IFN pathways in enterovirus A71 infections resulting in increased mortality and viral load (168). Severe infections with coxsackievirus have been associated with host expression of the decay-accelerating factor (DAF) and coxsackievirus and adenovirus receptor (CAR), which have been shown in mouse models to facilitate coxsackievirus infection of neural stem cells (169, 170). DAF and CAR are cell surface receptor proteins involved in the complement pathway (171) and cell adhesion (172), respectively. The role of DAF in disease is not known $(170,173)$. CAR functions as a receptor which can be used by coxsackieviruses to enter the cell (170). The immune response to enteroviral infections is varied and strain specific; however, a general strong pro-inflammatory response involving IL-1 $\alpha$, IL$1 \beta$ and TNF- $\alpha$, alongside an increase in the expression of innate immune receptors for double stranded RNA is observed in most cases (174). These responses alongside virally induced lytic cell death can result in extensive necrosis, further compounding the inflammatory response and potentially leading to conditions of sepsis (174). Interestingly, some strains of enterovirus, such as echovirus-9, seem to cause a particularly high degree of necrosis in pancreatic $\beta$ islet cells, resulting in a strong correlation between enteroviral infections and diabetes (174).

\section{Human Parechoviruses}

$\mathrm{HPeV} 3$ infection has been shown to initiate distinct innate immune responses in CNS infections to those of enteroviral infections despite their similar clinical presentations (175). Enteroviral responses are generally stronger; levels of almost all cytokines are higher in enteroviral responses than in $\mathrm{HPeV}$ infections. $\mathrm{HPeV}$ infections also do not demonstrate the strong type I IFN responses generally induced by RNA viruses. In addition, $\mathrm{HPeV}$ infections demonstrate a lower level of IL6 expression than both enterovirus infections and controls, suggesting some method of viral immune evasion (175), resulting in these muted immune responses. The markedly lower innate immune cytokine responses induced by $\mathrm{HPeV} 3$ infection are interesting, as $\mathrm{HPeV} 3$ has a similar clinical presentation to that of many enteroviral infections, raising questions about disease pathogenesis and viral classification. It has also been shown that $\mathrm{HPeV}$ is detected by TLRs 7 and 8 (176) which activate the type I IFN pathway (177). There is evidence that HPeVs (in particular HPeV type 1) employ methods to dampen type I IFN signalling (178) in a cell type dependent manner. Treatment of these cells with type I IFN, however, was not found to inhibit viral infection of these cells. It could be interesting to explore the relevance of this evasion mechanism in the context of a systemic infection. The immune response to $\mathrm{HPeV}$ infection is not as well-characterised as that of enteroviral infection; however, certain constants, such as the suppression of type I IFNs as an immune evasion mechanism, indicate that type I IFN pathways are important in the resolution of these infections. There are few data analysing cytokine populations of these infections in the context of sepsis, so while it is possible to characterise the immune responses involved in these infections, it is not known if these hold true in viral sepsis.
Several reasons have been proposed for why $\mathrm{HPeV} 3$ is more likely to cause severe infections than other HPeVs. It has been observed that $\mathrm{HPeV} 3$ lacks a sequence motif present in other $\mathrm{HPeVs}$ that is thought to play a role in viral use of integrins as host cell receptors, suggesting that the virus may be exploiting a different receptor to enter cells. This may allow it to more easily access host cells and thus replicate to a higher degree than other $\mathrm{HPeVs}$ (179). It has also been noted that HPeV3 is not efficiently neutralised by antibodies naturally generated against it, while $\mathrm{HPeV}$ type 1 was efficiently neutralised, which may explain why $\mathrm{HPeV} 3$ infections tend to be more severe. Maternal antibodies would be insufficient to neutralise the virus in a neonate, resulting in more severe, prolonged infections (180).

\section{Influenza Viruses}

Recognition of influenza virus is primarily through TLR3 (181), TLR4 (182), TLR7 (183), and RIG-I (184), which signal through $\mathrm{NF}-\kappa \mathrm{B}$ to induce subsequent immune responses (185). The polymorphisms of these receptors in different individuals in part determine their susceptibility to, and the severity of, influenza virus infection (186). The disruption of the alveolar epithelialendothelial barrier, leading to pulmonary oedema and further respiratory insufficiency, is essential to the development of severe pneumonia and ARDS caused by influenza virus (64). Influenza virus first infects alveolar epithelial cells rather than alveolar endothelial cells, which are usually the primary target for bacteria-induced ARDS $(64,187)$. Influenza virus can cause apoptosis of the epithelial cells by the upregulation of the Fas gene via activating protein kinase $\mathrm{R}$ (188). In addition, the infected epithelial cells produce a broad range of pro-inflammatory cytokines, such as TNF- $\alpha$, IL-1 $\beta$, IL-6, IL-8, CCL5 (RANTES), and CXCL10 (IP-10) (64). These cytokines can damage the epithelial-endothelial barrier through mechanisms that are not yet fully understood (64). Studies have demonstrated that IL-1 $\beta$ and TNF- $\alpha$ can cause decreased activity of amiloride-sensitive epithelial sodium channels, one of the key ion channels that clear alveolar fluid (189). TNF- $\alpha$ has also been shown to be able to disrupt the tight junctions between epithelial cells (190).

Some of the cytokines that are produced by epithelial cells can cause the recruitment and extravasation of monocytes and neutrophils by direct chemotaxis or upregulating adhesion molecules (e.g., P-selectin, E-selectin) on the endothelial cells (64). Newly-recruited neutrophils and macrophages, derived from monocytes, can produce a wide variety of pro-inflammatory cytokines, reactive oxygen species and nitric oxide (by inducible nitric oxide synthase), all of which further damage the barrier (64). These cytokines can also recruit more neutrophils and monocytes into the alveolar lumen (64). It has also been shown there is a positive correlation between the concentration of neutrophils in bronchoalveolar lavage fluid and the severity of ARDS (191). In addition, macrophages produce IFN- $\beta$ in a protein kinase $\mathrm{R}$ - and NF- $\kappa \mathrm{B}$-dependent fashion and express TNF-related apoptosis-inducing ligand (TRAIL) by the stimulation of IFN- $\beta$ (192). The interaction between TRAIL and death receptor 5 on epithelial cells is another mechanism for the apoptosis of epithelial cells (64). 


\section{Dengue Viruses}

The innate immune response to dengue infection is primarily characterised by an IL- 8 and type I IFN response activated by TLR3 after the virus is degraded by endosomal acidification (193). Dengue virus also activates the TLR7, TLR8, RIG-I and MDA5 signalling pathways, which signal through type I IFNs (194-196). There is also evidence that dengue virus may signal through TLRs 2 and 4, and that this may contribute to the pathogenesis and extreme inflammation of severe dengue (197). Type I IFN induction is important for a successful immune response to dengue virus (198). Many of the documented immune evasion mechanisms employed by dengue virus involve the inhibition of type I IFN signalling by some method. Dengue virus has been demonstrated to inhibit IFN production by a RIG-I dependent mechanism (199). Inhibition of IFN production contributes to the ability of dengue virus to replicate and spread, and thus to cause severe systemic infections and viral sepsis. Dengue virus can also cause an antibody enhanced form of disease when a patient is exposed to a different serotype of dengue virus than the one with which they were initially infected (70). Enhanced dengue disease involves the same immune responses as the non-enhanced form of disease, with a key difference being the presence of cross-reactive antibodies, which do not neutralise the pathogen but instead allow the virus to replicate within Fc receptor containing cells, resulting in a more severe infection (200).

\section{Immune Suppressive Phase of Viral Sepsis}

Figure 1B summarises the aberrant immune responses in viral sepsis. It has become apparent in recent years that the immunosuppression that results from sepsis may contribute more to mortality than the initial hyper-inflammatory response. A more immunosuppressive genotype in patients with sepsis is correlated with increased mortality $(201,202)$. It has also recently been reported that the majority of deaths in adults [68\%] that occur during sepsis from all causes happen on the third day or later (203). $20.4 \%$ of these deaths could be attributed to nosocomial infections. Independent predictors of third day or later death were corticosteroid treatment, no identification of the pathogen (203), and age. These risk factors differ in paediatric populations, with most deaths occurring within $48 \mathrm{~h}$ of presentation $(204,205)$. Most deaths in children occurred due to refractory shock (204). This suggests that in adults most sepsis related deaths are not due to an initial overpowering immune response, rather due to an inability to control infections that result in excessive pathogen proliferation and inflammation, whilst children are less able to survive an initial fulminant infection.

The initial inflammatory immune response that characterises viral sepsis is usually followed by a period of immune suppression. This phenomenon is characterised by decreased function in both innate and adaptive immunity, with common features including increased expression of negative costimulatory molecules and decreased expression of positive co-stimulatory molecules, $\mathrm{T}$ cell exhaustion, apoptosis of effector cells, increased regulatory $\mathrm{T}$ cell expression and higher numbers of myeloid derived suppressor cells $(206,207)$. This can result in increased infections from secondary pathogens, but also the reactivation of dormant infections, and natural microbiota becoming pathogenic (206). In particular, the reactivation of herpesviruses such as CMV and HSV have been found to occur in 33 and $21 \%$ of immunocompetent patients with severe infections requiring hospitalisation, respectively $(208,209)$. Due to the inability of the immune system to adequately control or eradicate these infections they can often result in severe disease (210), tissue damage, and even death. Mortality in sepsis is often caused by serious secondary infection after the initial inflammation has already passed. Immune suppression is a common feature of persistent and serious viral infections (211).

Some viral infections can directly result in immune suppression. Some strains of enterovirus are known to infect leucocytes (212). In particular some strains, such as coxsackievirus B3 and enterovirus 70, that have been implicated as causes of sepsis have shown this capacity (212). Infection of leucocytes in severe viral infections has been shown to result in an immunosuppressed state, as the death of infected leucocytes can result in a diminished ability to prime CD4 and CD8 cells and a reduced ability to control pathogens by phagocytosis. This greatly increases the susceptibility of the host to secondary infections (210). When compounded with other immune suppressive effects of severe infections, such as lymphocyte exhaustion, the ability to handle new infections can become drastically reduced (211). This phenomenon could explain the higher mortality observed in infections of relatively immunosuppressed patients, as well as the high level of mortality observed in sepsis after the initial inflammatory response has passed.

Serious infections that cause prolonged inflammation very often result in immune exhaustion. It was found in in vivo experiments that prolonged infections by a large variety of viruses can result in decreased differentiation of immature lymphocytes into CD8 T cells (213). Prolonged viral infections resulted in decreased expression of IL-7R $\alpha$, which in turn resulted in decreased numbers of circulating memory CD8 cells. It had also been observed that chronic infection with lymphocytic choriomeningitis virus (LCMV) resulted in poor CD8 T cell responses to cytokine stimulation and poor development of a memory CD8 response (214). A similar effect had been observed in a large number of mouse studies, suggesting that chronic viral infections could impair many aspects of CD8 effector T cell function (215-218).

Chronic viral infections have been found to have differential abilities to induce an immune suppressive state depending on the strain of virus. In a mouse model, high levels of $\mathrm{T}$ cell exhaustion have been induced by infections with LCMV, hepatitis B virus, hepatitis C virus, and HIV (217-221). Less pronounced immune exhaustion was produced in mouse CD8 cells by infection with Epstein-Barr virus (EBV), measles virus, and CMV (222-225). Why different chronic infections produce differing degrees of immune suppression is not well-understood, but could be due to novel immune evasion mechanisms, as in the case of HIV (220), the rate and degree of replication of a virus, its preferred replicative niche or its degree of interaction with PRRs. One well-characterised example of virally induced 
immunosuppression can be found in measles virus (225). Measles virus has several ways in which it can interact with the immune system and suppress responses. One of these is by interaction with the CD150 receptor to increase the apoptosis of immune effector cells while also decreasing expression of IFN- $\gamma$ (226). Infection with measles virus has also been shown to decrease the proliferation of lymphocytes for several weeks after the initial infection (227). One study found that measles virus infection may have immunosuppressive effects on the host immune system that can persist for 2-3 years (228). Although the mechanism by which this may occur was not characterised, it was hypothesised that measles virus employs a method of depleting memory B and $\mathrm{T}$ cells, resulting in a heightened susceptibility to infection by other pathogens (229). This process is multifactorial and not fully understood. One proposed mechanism is the inhibition of $\mathrm{T}$ cell replication by the measles virus proteins $\mathrm{H}$ and $\mathrm{F}_{1}-\mathrm{F}_{2}$ (230). It is possible that other viruses may utilise other immune evasion mechanisms that may result in immunosuppression.

Viral reactivation is a common feature of all forms of sepsis. As excessive inflammation gives way to immune exhaustion some latent infections can take advantage of this more forgiving environment, escape immunological control and replicate. Herpesviruses are most commonly associated with this phenomenon, owing to their ability to become latent for many years (231). Epidemiological studies have found CMV, EBV and HSV to be latent in around 50.4\% (232), 66.5\% (233), and 53.9\% (234) of the non-paediatric population of the United States, respectively, with detection of viral RNA (indicating active replication) in cases of sepsis occurring in 24.2, 53.2, and $14.1 \%$ of cases, respectively (235).

Some reactivated viral infections are particularly associated with increased mortality during sepsis. While viral reactivation is associated with higher mortality during sepsis, the contribution of individual viruses to mortality is still controversial. CMV reactivation has been associated with the doubling of mortality rates, which is comparable to the increase in mortality rate associated with latent HIV infection during sepsis (236). This model has been questioned however, and it is possible that the increased mortality attributed to CMV reactivation could be due to the reactivation of multiple viruses simultaneously. One study found no single virus to be significantly associated with higher mortality upon reactivation in sepsis, but found the reactivation of multiple viruses at once to significantly associate with worsened outcome (237). Further research on the contributions of the reactivation of individual virus strains to mortality is required.

It has also been hypothesised that viral reactivation may contribute to a feedback loop within sepsis, wherein the reactivated viruses contribute even further to $\mathrm{T}$ cell exhaustion and immunosuppression, resulting in even greater susceptibility to viremia, compounded immune suppression (235) and elevated inflammation. This feedback loop would explain why a high degree of viral reactivation (of all viruses) correlates with increased mortality. It is still unclear whether elevated viral loads of herpesviruses following reactivation indeed impairs lymphocyte function or whether it is just a side effect of other kinds of immune suppression already taking place (238). It has been demonstrated that CMV infection can have an effect on the differentiation of immature lymphocytes into effector CD8 T cells; however, the overall effects this may have on the patient are not well-characterised $(239,240)$. The state of CD8 differentiation brought about by CMV infection is similar to the differentiation state of CD8 T cells in older adults. This suggests that CMV infection may contribute to immunosuppression, but more research is required to confirm if this effect has a significant effect on mortality during severe infections (240). Immunosuppressive effects have also been observed in EBV infection. EBV infection was found to be associated with reduced antibody responses to vaccines in Gambian infants (241). The mechanism of this is still not yet known. Interestingly CMV infection was not found to be associated with these lowered responses (241). In addition, there is evidence that these reactivated viral infections contribute to inflammation alongside any immunosuppressive effects, resulting in a heightened state of inflammation but without the capacity to resolve it. In particular, HSV and CMV have been associated with inflammatory responses upon reactivation $(242,243)$. Whether or not this phenomenon contributes significantly to mortality during sepsis is still controversial (235).

Understanding the role viral reactivation plays in the immunosuppressive phase and in the pathology of sepsis may provide avenues to treatment in the future. Possible approaches would be the application of antiviral medications specific to viruses that commonly experience reactivation, or drugs that could prevent immune exhaustion or ameliorate its effects (like inhibitors of negative co-stimulatory molecules discussed below). An improved understanding of the effects of viral reactivation is vital to expanding our understanding of sepsis and will contribute to better categorisation of illness and application of more appropriate treatments.

\section{IS VIRAL SEPSIS DIFFERENT FROM BACTERIAL SEPSIS?}

The diagnosis of viral sepsis can be useful to inform treatment in cases where antiviral medications are available and suitable; however, immunological data are scarce on viral sepsis. It cannot be said with any certainty if viral sepsis is meaningfully different from bacterial sepsis. Viral sepsis is only understood insofar as immune responses involved in severe viral infections are understood. The causes and character of sepsis can be highly heterogeneous (206). While knowledge of the causative pathogen provides with treatment options against that pathogen and against associated immune responses, sepsis and subtypes thereof are not characterised well enough for immune responsebased therapies to proliferate and enter the mainstream. An important next step in the understanding of sepsis will be the characterisation and grouping of sepsis cases according to some criteria that may inform treatment, and the discovery of cheap and effective biomarkers which would allow these criteria to be defined.

Studies have been conducted which have aimed to develop methods to discriminate between viral and bacterial infections 
(244-246). Some of these have analysed transcriptomics to identify gene signatures that can differentiate between viral and bacterial infections (244-246). Some genes identified in these studies include genes downstream of the IFN signalling pathways such as IFN-stimulated gene 15 (245) and IFN- $\alpha$-inducible protein 27 (244) as well as cytokines such as IL-16 (245). The roles these genes play in viral infection is not yet known; however, that information is not required for their use as biomarkers, and as such they may have clinical utility regardless. The results of these studies may inform future research to identify biomarkers which can be used in a clinical setting to quickly differentiate between bacterial and viral infections. Applications of these methods to cases of sepsis may help us develop an understanding of how sepsis differs for differing aetiologies. Transcriptomic studies in sepsis have been performed before as discussed above $(201,202)$, but more focused studies aiming to understand the pathogen's role in the character of the disease will be essential to future sepsis research and providing an answer to the mysteries of viral sepsis. It may prove difficult to recruit sufficient sample sizes for a highly powered transcriptomics study in viral sepsis due to its underdiagnosis.

\section{TREATMENTS FOR VIRAL INFECTIONS AND SEPSIS}

Up to $42 \%$ of all cases of sepsis are culture negative, suggesting a possible non-bacterial cause of infection (21), if appropriate tests have been performed. Despite this, however, the preferred treatment of sepsis in all cases is the early administration of broad-spectrum antibiotics. The survival rate of patients presenting with septic shock decreases by an average of $7.6 \%$ for every hour that antimicrobials are not applied (247), with time to application of antimicrobial therapy being the single greatest indicator of outcome in the multivariate analysis performed in one study (247). However, the administration of antibiotics will not be effective in the case of viral sepsis and can be associated with adverse effects. Understanding a potential viral cause of the disease increases the possible treatment options, opening the possibility of using broad-spectrum antiviral medications, but also to treatments built on an understanding of both sepsis, and how the immune response to pathogens may contribute to it.

Prospective treatments for specific viruses implicated in sepsis are being developed. Pleconaril is an antiviral against enteroviral infection which inhibits viral attachment to the hosts cell receptors and prevents uncoating of the viral nucleic acids. There are data suggesting that the drug would be effective and safe in neonatal virally induced sepsis (248). The drug recently completed a small phase 2 clinical trial (248); however, it is no longer under development and is not available, even for compassionate use. The benefits of more effective antiviral medicines are clear. They could help both in cases of severe viral infections and sepsis while also providing treatment for more benign infections. It could prove useful to use such drugs alongside antibiotics in sepsis cases, to allow for the possibility of a viral cause, although this would also open the possibility of the development of viral resistance. There are many specific antiviral drugs that have been developed and gone through trials; however, none have yet been tested specifically for sepsis. Examples that may be beneficial in presentations of sepsis in certain situations include acyclovir, which has been proven effective in HSV infections (249), amantadine, rimantadine, oseltamivir, and zanamivir for influenza $(250,251)$, and more broad-spectrum antiviral drugs like ribavirin and favipiravir (250).

Antiviral medicines may also have a role in the treatment of viral reactivation, which may improve outcomes even in nonvirally induced sepsis. Ganciclovir has been demonstrated to measurably decrease CMV reactivation in mice (248); however, human trials did not show any significant decrease in CMVinduced inflammatory cytokine levels (252). There have been numerous other drugs developed against CMV (253) which could be effective in preventing viral reactivation.

With the advent of research into personalised medicine, the idea of treating the host immune response in sepsis has become popular. By understanding the host response to pathogens and modifying it we may prevent serious infections that can result in sepsis or sepsis-like-illness. One common strategy of treating the host response is the use of immunomodulatory molecules to prevent harmful excessive inflammation in infections. Immunomodulation in sepsis aims to decrease the harmful effects of excessive inflammation by altering or counteracting the effects of inflammatory mediator molecules (254), such as TNF- $\alpha$ (255) or by using broad anti-inflammatory molecules, such as corticosteroids (256). Most trials for immunomodulatory drugs, however, have failed (257). This approach, has fallen out of favour in recent years as it either proves ineffective [e.g., dengue $(258,259)]$ or in some cases has the opposite of the desired effect and dampen the immune system in such a way as to allow the pathogen freedom to replicate and proliferate into an uncontrolled infection that causes greater harm [e.g., corticosteroids in influenza $(260,261)]$. However, adjunctive corticosteroid therapy may be beneficial and can be considered in patients with varicella zoster virus encephalitis $(262,263)$ or HSV encephalitis (264).

In recent years, an immunostimulatory approach to immunotherapy against sepsis has become much more popular (265). This approach aims to promote rapid pathogen clearance, decreasing the chance for it to proliferate and cause a more severe infection (265). One proposed method of doing this is selective application of immunostimulatory cytokines such as IL-7 and granulocyte-macrophage colony-stimulating factor (GM-CSF) which some studies have shown to contribute to more effective viral clearance $(266,267)$. A recent study demonstrated that the majority of deaths which occur due to sepsis occur on the third day or later (203), after immunosuppression has taken hold, suggests an immunostimulatory approach may prove to be beneficial.

In order for the treatment of the immune response to work as a meaningful way to decrease overall mortality we must better understand how the immune response to infections contributes to the development of sepsis. To this end, the development of biomarkers that could determine the likelihood of an infection becoming harmful due to a lack of ability to clear an infection, 
or indeed whether the initial immune response will be excessive and harmful, would make these relatively brute force treatments much more effective by timing and targeting their application. An understanding of the excessive inflammatory response to pathogens will allow us to better categorise sepsis states, and group them according to treatability. Some strides forward have been made in this field. A 2016 study (201) identified two distinct host response signatures to sepsis by unsupervised hierarchical clustering, one of which significantly associated with higher 14-day mortality. While this study only analysed bacterial sepsis, the methodology would be extremely useful in expanding our understanding of viral sepsis. The identified signature was characterised by relative immunosuppression as well as increased tolerance to endotoxins, $\mathrm{T}$ lymphocyte exhaustion and metabolic dysfunction. It was hypothesised that these individuals experienced more severe disease due to an inability to control infections, resulting in increased pathogen replication. These individuals would also be more susceptible to secondary infection. This study, however, only examined sepsis in adult patients with community acquired pneumonia, which is not necessarily informative of paediatric populations with immature immune systems, other immunocompromised groups or viral infections. A similar study focusing primarily on viral sepsis would be invaluable to the understanding of viral sepsis and would open numerous new avenues for prospective treatments. To be effective in a clinical setting this approach will require the development of rapid transcriptomic analysis methods to be clinically useful in a case of a patient acutely presenting with sepsis. Another study aiming to identify a predictive genomic signature had similar results (202), grouping cases of sepsis using a hierarchical clustering method into two distinct subgroups, one of which correlated with a higher rate of mortality, and was characterised by a more immunosuppressed phenotype. Genes involved in the function of lymphocytes were suppressed, despite the relatively high lymphocyte counts in patients in this group. This study had similar limitations to the other study mentioned above.

This knowledge could potentially be used to inform treatment and the development of immunotherapeutics. It was suggested that patients presenting with this immunosuppressed gene expression signature may benefit from drugs that modulate aspects of the immune response, for example treatment with various cytokines (such as IFN- $\gamma$, IL-7, or IL-15) or blockade of receptors that can induce cell death in T lymphocytes (201), such as programmed death 1 (PD-1).

The PD-1 ligand is a promising target for the treatment of viral sepsis. PD-1 has been implicated in the development of the immunosuppressive phase of sepsis by inducing the apoptosis of effector T cells. Continued elevation of PD-1 expression in septic patients has been found to correlate highly with patient mortality (238). PD-1 has been implicated in the pathogenesis of highly pathogenic influenza infections. In more severe Influenza infections PD-1 was expressed at a higher level, while blocking it led to increased CD8+ numbers and reduced viral titres in vivo (268). Blocking of PD-1 may allow for vastly improved clearance of serious viral infections, preventing the patient from becoming septic. PD-1 blockade treatment may also be useful in the immunosuppressive phase of sepsis by maintaining the competence of the immune system to clear secondary infections and thus decreasing overall mortality (269-271).

One common feature of sepsis that has emerged as a promising target for treatments is the dysregulation of endothelial barriers (272). The endothelial barrier is a continuous layer coating the vascular system which separates the fluid from the tissue compartments. The barrier is important in maintaining bodily homeostasis, regulating the passage of gases, liquids, proteins, cells and micro-organisms, among other things from the blood into the tissues. This dysregulation has been found to be central to the pathology of sepsis (273). In states of septic shock the tight junctions between cells become disrupted due to platelets and neutrophils adhering to the endothelial wall, the release of inflammatory and toxic mediators by these cells, and an increased expression of binding molecules like selectins and integrins, which allow leucocytes to bind to the endothelial layer, and then migrate through it (274). The process of dysregulation also compounds any damage to the endothelial barrier by increasing the level of inflammatory mediators at its surface. This leads to fluid leaking into interstitial tissues, and the recruitment of macrophages and other inflammatory cells to tissues they cannot normally access resulting in tissue damage (272). While these responses generally allow immune effector cells to reach sites of localised infection or damage, during the dysregulation and move away from homeostasis that occurs in sepsis, they can allow for considerable damage to be done to tissues.

This phenomenon has been found to also occur in serious viral infections, and also plays a major role in the pathology of viral sepsis in these cases (275). Viruses such as hantavirus, dengue viruses, and HSV have presentations that suggest a role for the endothelial barrier in the pathogenesis of serious disease (276). There is a lack of data on the relevance of endothelial leaking in most other viral infections; however, there is evidence that it is involved in the pathogenesis of avian influenza A (H5N1) virus, which produces a cytokine storm effect (277), and is known to increase vascular permeability and immune cell infiltration into the tissues.

Therefore, endothelial barrier dysfunction presents an attractive target for the treatment of severe viral infections and sepsis. There are several drugs which are known to help preserve endothelial integrity which may be of use in treating severe viral infections or sepsis. These include common medications such as statins and angiotensin receptor blockers (278), which have proven benefits in both sepsis, influenza and other critical illnesses. They are thought to work by maintaining or restoring endothelial barrier integrity (278) and could be promising treatments of viral infections known to disrupt endothelial integrity. These drugs have had some success in treating severe viral infections such as Ebola and influenza (279-281) suggesting their use in viral sepsis is a promising area for future research. One trial aimed to control the severity of sepsis using the drug "atorvastatin." The trial, while aborted due to subpar recruitment, demonstrated interesting results. It was calculated that assuming the drug would bring about a $15 \%$ reduction in cases of progression to sepsis, 414 patients would be required 
to achieve statistical significance. While only a quarter of this number were recruited, an $83 \%$ decrease in progression to sepsis (from all causes) was observed, far exceeding expectations (282). However, due to the insufficient sample size, the result was insignificant (282). With the addition of more data these results would suggest that statins may be a particularly promising route for further research particularly in cases of viruses known to interfere with endothelial barrier function.

\section{CONCLUSIONS}

Viral sepsis is a continually underdiagnosed and heterogeneous form of sepsis that can be caused by a wide variety of viruses. The most common of these pathogens are HSV, enteroviruses, HPeVs, influenza, and dengue viruses. Some populations are at a much higher risk of viral sepsis than others for many reasons. The populations at the highest risk are young children, pregnant women, older adults, and immunosuppressed individuals. This heightened risk and severity is due to relative immunosuppression present in these populations. The viruses that most often cause viral sepsis tend to have the capacity to evade killing by the immune system while still inducing powerful inflammatory responses, often characterised by high levels of TNF- $\alpha$ and IL- 6 expression alongside low IFN- $\gamma$ expression that can damage the host. The prolonged inflammation that can be brought on by these infections can then result in an immunosuppressed state, further reducing the body's capacity to clear infections, and drastically increasing the risk of death from the original viral infection, a newly acquired infection or a reactivated infection. Understanding the viral cause of sepsis and the immune responses to common viral infections could lead to improved treatment of sepsis by use of specific antiviral medications. In the future it may be possible to apply immunotherapies built around the understanding of the specifics of viral infections to either aid in viral clearance or

\section{REFERENCES}

1. Singer M, Deutschman CS, Seymour CW, Shankar-Hari M, Annane D, Bauer $\mathrm{M}$, et al. The Third International Consensus definitions for sepsis and septic shock (Sepsis-3). JAMA (2016) 315:801-10. doi: 10.1001/jama. 2016.0287

2. Bone RC, Balk RA, Cerra FB, Dellinger RP, Fein AM, Knaus WA, et al. Definitions for sepsis and organ failure and guidelines for the use of innovative therapies in sepsis. The ACCP/SCCM Consensus Conference Committee. American College of Chest Physicians/Society of Critical Care Medicine. Chest (1992) 101:1644-55.

3. Levy MM, Fink MP, Marshall JC, Abraham E, Angus D, Cook D, et al. 2001 SCCM/ESICM/ACCP/ATS/SIS International Sepsis Definitions Conference. Intensive Care Med. (2003) 29:530-8. doi: 10.1007/s00134-003-1662-x

4. Simpson SQ. SIRS in the time of Sepsis-3. Chest (2018) 153:34-8. doi: 10.1016/j.chest.2017.10.006

5. Fleischmann-Struzek C, Goldfarb DM, Schlattmann P, Schlapbach LJ, Reinhart K, Kissoon N. The global burden of paediatric and neonatal sepsis: a systematic review. Lancet Respir Med. (2018) 6:223-30. doi: 10.1016/s2213-2600(18)30063-8

6. Goldstein B, Giroir B, Randolph A, International Consensus Conference on Pediatric Sepsis. International pediatric sepsis consensus conference: reduce harm from viral infections. Sepsis from differing causes seems to differ little in its clinical presentation; however, use of modern transcriptomic methods is demonstrating that there are meaningful differences in immune responses that may be used to distinguish between viral and bacterial sepsis, which may aid in the development of future immunomodulatory drugs.

\section{AUTHOR CONTRIBUTIONS}

AP, G-LL, and JM conceived the topic and scope of this review. G-LL and JM drafted the first version of the manuscript. G-LL compiled the table. JM designed the figure. AP and SD provided critical revision of the manuscript. All authors made significant editorial contributions, read and approved the submitted version of the article.

\section{ACKNOWLEDGMENTS}

We acknowledge the support of the National Institute for Health Research (NIHR) Oxford Biomedical Research Centre and the NIHR Thames Valley and South Midlands Clinical Research Network. We acknowledge the support of the British Research Council (BRC) and the REspiratory Syncytial virus Consortium in EUrope (RESCEU) consortium which has received funding from the Innovative Medicines Initiative 2 Joint Undertaking under grant agreement No 116019. This Joint Undertaking receives support from the European Union's Horizon 2020 research and innovation programme and European Federation of Pharmaceutical Industries and Associations (EFPIA). AP is an NIHR Senior Investigator with funding from the BRC. JM is an IMI-funded researcher. The views expressed in this article are those of the authors and not necessarily those of the NHS, the NIHR, or the Department of Health.

definitions for sepsis and organ dysfunction in pediatrics. Pediatr Crit Care Med. (2005) 6:2-8. doi: 10.1097/01.Pcc.0000149131.72248.E6

7. Wiens MO, Larson CP, Kumbakumba E, Kissoon N, Ansermino JM, Singer J, et al. Application of sepsis definitions to pediatric patients admitted with suspected infections in Uganda. Pediatr Crit Care Med. (2016) 17:400-5. doi: $10.1097 /$ pcc. 0000000000000708

8. Schlapbach LJ, Straney L, Bellomo R, MacLaren G, Pilcher D. Prognostic accuracy of age-adapted SOFA, SIRS, PELOD-2, and qSOFA for inhospital mortality among children with suspected infection admitted to the intensive care unit. Intensive Care Med. (2018) 44:179-88. doi: 10.1007/s00134-017-5021-8

9. Schlapbach LJ, Kissoon N. Defining pediatric sepsis. JAMA Pediatr. (2018) 172:312-4. doi: 10.1001/jamapediatrics.2017.5208

10. Matics TJ, Sanchez-Pinto LN. Adaptation and validation of a pediatric sequential organ failure assessment score and evaluation of the sepsis3 definitions in critically ill children. JAMA Pediatr. (2017) 171:e172352. doi: 10.1001/jamapediatrics.2017.2352

11. Leteurtre S, Duhamel A, Salleron J, Grandbastien B, Lacroix J, Leclerc F, et al. PELOD-2: an update of the PEdiatric Logistic Organ Dysfunction score. Crit Care Med. (2013) 41:1761-73. doi: 10.1097/CCM.0b013e31828a2bbd

12. Leclerc F, Duhamel A, Deken V, Grandbastien B, Leteurtre S, Groupe Francophone de Réanimation et Urgences Pédiatriques (GFRUP). Can the 
pediatric logistic organ dysfunction-2 score on day 1 be used in clinical criteria for sepsis in children? Pediatr Crit Care Med. (2017) 18:758-63. doi: $10.1097 / \mathrm{pcc} .0000000000001182$

13. Schlapbach LJ, Berger C, Aebi C, Agyeman PKA. SIRS in the time of Sepsis-3: what about the children? Chest (2018) 153:1512. doi: $10.1016 /$ j.chest.2018.02.037

14. Schlapbach LJ. Time for Sepsis-3 in Children? Pediatr Crit Care Med. (2017) 18:805-6. doi: 10.1097/pcc.0000000000001203

15. Lin R, Liu Q. Diagnosis and treatment of viral diseases in recipients of allogeneic hematopoietic stem cell transplantation. J Hematol Oncol. (2013) 6:94. doi: 10.1186/1756-8722-6-94

16. Vincent JL, Lefrant JY, Kotfis K, Nanchal R, Martin-Loeches I, Wittebole X, et al. Comparison of European ICU patients in 2012 (ICON) versus 2002 (SOAP). Intensive Care Med. (2018) 44:337-44. doi: 10.1007/s00134-017-5043-2

17. Fleischmann C, Scherag A, Adhikari NK, Hartog CS, Tsaganos T, Schlattmann P, et al. Assessment of global incidence and mortality of hospital-treated sepsis. current estimates and limitations. Am J Respir Crit Care Med. (2016) 193:259-72. doi: 10.1164/rccm.201504-0781OC

18. Meyer N, Harhay MO, Small DS, Prescott HC, Bowles KH, Gaieski $\mathrm{DF}$, et al. Temporal trends in incidence, sepsis-related mortality, and hospital-based acute care after sepsis. Crit Care Med. (2018) 46:354-60. doi: $10.1097 / \mathrm{ccm} .0000000000002872$

19. Martin GS, Mannino DM, Eaton S, Moss M. The epidemiology of sepsis in the United States from 1979 through 2000. N Engl J Med. (2003) 348:154654. doi: 10.1056/NEJMoa022139

20. GBD 2015 Mortality and Causes of Death Collaborators. Global, regional, and national life expectancy, all-cause mortality, and cause-specific mortality for 249 causes of death, 1980-2015: a systematic analysis for the Global Burden of Disease Study 2015. Lancet (2016) 388:1459-544. doi: 10.1016/s0140-6736(16)31012-1

21. Phua J, Ngerng W, See K, Tay C, Kiong T, Lim H, et al. Characteristics and outcomes of culture-negative versus culture-positive severe sepsis. Crit Care (2013) 17:R202. doi: 10.1186/cc12896

22. Zahar JR, Timsit JF, Garrouste-Orgeas M, Français A, Vesin A, Vesim A, et al. Outcomes in severe sepsis and patients with septic shock: pathogen species and infection sites are not associated with mortality. Crit Care Med. (2011) 39:1886-95. doi: 10.1097/CCM.0b013e31821b827c

23. Blanco J, Muriel-Bombín A, Sagredo V, Taboada F, Gandía F, Tamayo L, et al. Incidence, organ dysfunction and mortality in severe sepsis: a Spanish multicentre study. Crit Care (2008) 12:R158. doi: 10.1186/cc7157

24. Southeast Asia Infectious Disease Clinical Research Network. Causes and outcomes of sepsis in southeast Asia: a multinational multicentre cross-sectional study. Lancet Glob Health (2017) 5:e157-67. doi: $10.1016 / \mathrm{s} 2214-109 \mathrm{x}(17) 30007-4$

25. Novel Swine-Origin Influenza A (H1N1) Virus Investigation Team, Dawood FS, Jain S, Finelli L, Shaw MW, Lindstrom S, et al. Emergence of a novel swine-origin influenza A (H1N1) virus in humans. N Engl J Med. (2009) 360:2605-15. doi: 10.1056/NEJMoa0903810

26. Fox JP, Hall CE, Cooney MK. The Seattle Virus Watch. VII. Observations of adenovirus infections. Am J Epidemiol. (1977) 105:362-86.

27. Choi SH, Hong SB, Ko GB, Lee Y, Park HJ, Park SY, et al. Viral infection in patients with severe pneumonia requiring intensive care unit admission. Am J Respir Crit Care Med. (2012) 186:325-32. doi: 10.1164/rccm.201112-2240OC

28. Vincent JL, Sakr Y, Sprung CL, Ranieri VM, Reinhart K, Gerlach H, et al. Sepsis in European intensive care units: results of the SOAP study. Crit Care Med. (2006) 34:344-53. doi: 10.1097/01.CCM.0000194725.48928.3A

29. Simonsen KA, Anderson-Berry AL, Delair SF, Davies HD. Earlyonset neonatal sepsis. Clin Microbiol Rev. (2014) 27:21-47. doi: $10.1128 / \mathrm{cmr} .00031-13$

30. Schuetz P, Amin DN, Greenwald JL. Role of procalcitonin in managing adult patients with respiratory tract infections. Chest (2012) 141:1063-73. doi: 10.1378/chest.11-2430

31. Seventieth World Health Assembly. Improving the Prevention, Diagnosis and Clinical Management of Sepsis (WHA70.7) (2017). Available online at: http://apps.who.int/gb/ebwha/pdf_files/WHA70/A70_R7-en.pdf (Accessed May 10, 2018).
32. Shane AL, Sánchez PJ, Stoll BJ. Neonatal sepsis. Lancet (2017) 390:1770-80. doi: 10.1016/s0140-6736(17)31002-4

33. Wolthers KC, Benschop KS, Schinkel J, Molenkamp R, Bergevoet RM, Spijkerman IJ, et al. Human parechoviruses as an important viral cause of sepsislike illness and meningitis in young children. Clin Infect Dis. (2008) 47:358-63. doi: 10.1086/589752

34. World Health Organization. Vaccines against influenza WHO position paper - November 2012. Wkly Epidemiol Rec. (2012) 87:461-76.

35. Chowell G, Bertozzi SM, Colchero MA, Lopez-Gatell H, Alpuche-Aranda $C$, Hernandez $M$, et al. Severe respiratory disease concurrent with the circulation of H1N1 influenza. N Engl J Med. (2009) 361:674-9. doi: 10.1056/NEJMoa0904023

36. Pinninti SG, Kimberlin DW. Neonatal herpes simplex virus infections. Pediatr Clin North Am. (2013) 60:351-65. doi: 10.1016/j.pcl.2012.12.005

37. Haag LM, Hofmann J, Kredel LI, Holzem C, Kühl AA, Taube ET, et al. Herpes simplex virus sepsis in a young woman with Crohn's disease. JCrohns Colitis (2015) 9:1169-73. doi: 10.1093/ecco-jcc/jjv149

38. Kaufman B, Gandhi SA, Louie E, Rizzi R, Illei P. Herpes simplex virus hepatitis: case report and review. Clin Infect Dis. (1997) 24:334-8.

39. Corey L, Wald A. Maternal and neonatal herpes simplex virus infections. $N$ Engl J Med. (2009) 361:1376-85. doi: 10.1056/NEJMra0807633

40. Brown EL, Gardella C, Malm G, Prober CG, Forsgren M, Krantz EM, et al. Effect of maternal herpes simplex virus (HSV) serostatus and HSV type on risk of neonatal herpes. Acta Obstet Gynecol Scand. (2007) 86:523-9. doi: 10.1080/00016340601151949

41. Kropp RY, Wong T, Cormier L, Ringrose A, Burton S, Embree JE, et al. Neonatal herpes simplex virus infections in Canada: results of a 3-year national prospective study. Pediatrics (2006) 117:1955-62. doi: 10.1542/peds.2005-1778

42. Brown ZA, Wald A, Morrow RA, Selke S, Zeh J, Corey L. Effect of serologic status and cesarean delivery on transmission rates of herpes simplex virus from mother to infant. JAMA (2003) 289:203-9. doi: 10.1001/jama.289. 2.203

43. Khetsuriani N, Lamonte-Fowlkes A, Oberst S, Pallansch MA, Centers for Disease Control and Prevention. Enterovirus surveillance-United States, 1970-2005. MMWR Surveill Summ. (2006) 55:1-20.

44. Nathan M, Walsh R, Hardin JT, Einzig S, Connor BO, Balaguru D, et al. Enteroviral sepsis and ischemic cardiomyopathy in a neonate: case report and review of literature. ASAIO J. (2008) 54:554-5. doi: 10.1097/MAT.0b013e3181877fc5

45. Khetsuriani N, Lamonte A, Oberste MS, Pallansch M. Neonatal enterovirus infections reported to the national enterovirus surveillance system in the United States, 1983-2003. Pediatr Infect Dis J. (2006) 25:889-93. doi: 10.1097/01.inf.0000237798.07462.32

46. Piralla A, Mariani B, Stronati M, Marone P, Baldanti F. Human enterovirus and parechovirus infections in newborns with sepsis-like illness and neurological disorders. Early Hum Dev. (2014) 90(Suppl. 1):S75-7. doi: 10.1016/s0378-3782(14)70023-4

47. Rhoades RE, Tabor-Godwin JM, Tsueng G, Feuer R. Enterovirus infections of the central nervous system. Virology (2011) 411:288-305. doi: 10.1016/j.virol.2010.12.014

48. Ho M, Chen ER, Hsu KH, Twu SJ, Chen KT, Tsai SF, et al. An epidemic of enterovirus 71 infection in Taiwan. Taiwan Enterovirus Epidemic Working Group. N Engl J Med. (1999) 341:929-35. doi: 10.1056/nejm199909233411301

49. Chang LY, Lin TY, Hsu KH, Huang YC, Lin KL, Hsueh C, et al. Clinical features and risk factors of pulmonary oedema after enterovirus71-related hand, foot, and mouth disease. Lancet (1999) 354:1682-6. doi: 10.1016/s0140-6736(99)04434-7

50. Huang WC, Shih WL, Yang SC, Yen TY, Lee JT, Huang YC, et al. Predicting severe enterovirus 71 infection: Age, comorbidity, and parental behavior matter. J Microbiol Immunol Infect. (2017) 50:10-6. doi: 10.1016/j.jmii.2014.11.013

51. Modlin JF. Perinatal echovirus infection: insights from a literature review of 61 cases of serious infection and 16 outbreaks in nurseries. Rev Infect Dis. (1986) 8:918-26.

52. Westerhuis B, Kolehmainen P, Benschop K, Nurminen N, Koen G, Koskiniemi M, et al. Human parechovirus seroprevalence in Finland and 
the Netherlands. J Clin Virol. (2013) 58:211-5. doi: 10.1016/j.jcv.2013. 06.036

53. Gupta S, Fernandez D, Siddiqui A, Tong WC, Pohl K, Jungbluth H. Extensive white matter abnormalities associated with neonatal Parechovirus (HPeV) infection. Eur J Paediatr Neurol. (2010) 14:531-4. doi: 10.1016/j.ejpn.2009.12.007

54. Britton PN, Dale RC, Nissen MD, Crawford N, Elliott E, Macartney K, et al. Parechovirus encephalitis and neurodevelopmental outcomes. Pediatrics (2016) 137:e20152848. doi: 10.1542/peds.2015-2848

55. Khatami A, McMullan BJ, Webber M, Stewart P, Francis S, Timmers $\mathrm{KJ}$, et al. Sepsis-like disease in infants due to human parechovirus type 3 during an outbreak in Australia. Clin Infect Dis. (2015) 60:228-36. doi: $10.1093 / \mathrm{cid} / \mathrm{ciu} 784$

56. Harvala H, Robertson I, Chieochansin T, McWilliam Leitch EC, Templeton $\mathrm{K}$, Simmonds P. Specific association of human parechovirus type 3 with sepsis and fever in young infants, as identified by direct typing of cerebrospinal fluid samples. J Infect Dis. (2009) 199:1753-60. doi: 10.1086/599094

57. Esposito S, Rahamat-Langendoen J, Ascolese B, Senatore L, Castellazzi L, Niesters HG. Pediatric parechovirus infections. J Clin Virol. (2014) 60:84-9. doi: $10.1016 /$ j.jcv.2014.03.003

58. Cabrerizo M, Trallero G, Pena MJ, Cilla A, Megias G, Muñoz-Almagro C, et al. Comparison of epidemiology and clinical characteristics of infections by human parechovirus vs. those by enterovirus during the first month of life. Eur J Pediatr. (2015) 174:1511-6. doi: 10.1007/s00431-0152566-9

59. Iuliano AD, Roguski KM, Chang HH, Muscatello DJ, Palekar R, Tempia S, et al. Estimates of global seasonal influenza-associated respiratory mortality: a modelling study. Lancet (2018) 391:1285-300. doi: 10.1016/s0140-6736(17)33293-2

60. Green HK, Andrews N, Fleming D, Zambon M, Pebody R. Mortality attributable to influenza in England and Wales prior to, during and after the 2009 pandemic. PLoS ONE (2013) 8:e79360. doi: 10.1371 /journal.pone. 0079360

61. Dawood FS, Iuliano AD, Reed C, Meltzer MI, Shay DK, Cheng PY, et al. Estimated global mortality associated with the first 12 months of 2009 pandemic influenza A H1N1 virus circulation: a modelling study. Lancet Infect Dis. (2012) 12:687-95. doi: 10.1016/s1473-3099(12)70121-4

62. Monsalvo AC, Batalle JP, Lopez MF, Krause JC, Klemenc J, Hernandez JZ, et al. Severe pandemic $2009 \mathrm{H} 1 \mathrm{~N} 1$ influenza disease due to pathogenic immune complexes. Nat Med. (2011) 17:195-9. doi: 10.1038/nm.2262

63. Florescu DF, Kalil AC. The complex link between influenza and severe sepsis. Virulence (2014) 5:137-42. doi: 10.4161/viru.27103

64. Short KR, Veldhuis Kroeze EJB, Fouchier RAM, Kuiken T. Pathogenesis of influenza-induced acute respiratory distress syndrome. Lancet Infect Dis. (2014) 14:57-69. doi: 10.1016/s1473-3099(13)70286-x

65. Fukuyama S, Kawaoka Y. The pathogenesis of influenza virus infections: the contributions of virus and host factors. Curr Opin Immunol. (2011) 23:481-6. doi: 10.1016/j.coi.2011.07.016

66. Shinya K, Ebina M, Yamada S, Ono M, Kasai N, Kawaoka Y. Avian flu: influenza virus receptors in the human airway. Nature (2006) 440:435-6. doi: $10.1038 / 440435$ a

67. Weinheimer VK, Becher A, Tönnies M, Holland G, Knepper J, Bauer TT, et al. Influenza A viruses target type II pneumocytes in the human lung. $J$ Infect Dis. (2012) 206:1685-94. doi: 10.1093/infdis/jis455

68. Murray NE, Quam MB, Wilder-Smith A. Epidemiology of dengue: past, present and future prospects. Clin Epidemiol. (2013) 5:299-309. doi: $10.2147 /$ clep.S34440

69. Wilder-Smith A, Ooi EE, Vasudevan SG, Gubler DJ. Update on dengue: epidemiology, virus evolution, antiviral drugs, and vaccine development. Curr Infect Dis Rep. (2010) 12:157-64. doi: 10.1007/s11908-010-0102-7

70. Katzelnick LC, Gresh L, Halloran ME, Mercado JC, Kuan G, Gordon A, et al. Antibody-dependent enhancement of severe dengue disease in humans. Science (2017) 358:929-32. doi: 10.1126/science.an6836

71. Teparrukkul P, Hantrakun V, Day NPJ, West TE, Limmathurotsakul D. Management and outcomes of severe dengue patients presenting with sepsis in a tropical country. PLoS ONE (2017) 12:e0176233. doi: 10.1371 /journal.pone. 0176233
72. Abzug MJ. Nonpolio enteroviruses. In: Kliegman RM, Stanton BMD, St. Geme J, Schor NF, editors. Nelson Textbook of Pediatrics. Vol 1. Philadelphia, PA: Elsevier Health Sciences (2015). p. 1561-8.

73. de Jong EP, van den Beuken MGA, van Elzakker EPM, Wolthers KC, Sprij AJ, Lopriore E, et al. Epidemiology of sepsis-like illness in young infants: major role of enterovirus and human parechovirus. Pediatr Infect Dis J. (2018) 37:113-8. doi: 10.1097/inf.0000000000001718

74. Nair H, Brooks WA, Katz M, Roca A, Berkley JA, Madhi SA, et al. Global burden of respiratory infections due to seasonal influenza in young children: a systematic review and meta-analysis. Lancet (2011) 378:1917-30. doi: 10.1016/s0140-6736(11)61051-9

75. Wu P, Goldstein E, Ho LM, Yang L, Nishiura H, Wu JT, et al. Excess mortality associated with influenza A and B virus in Hong Kong, 1998-2009. J Infect Dis. (2012) 206:1862-71. doi: 10.1093/infdis/jis628

76. Special Programme for Research Training in Tropical Diseases, World Health Organization. Dengue: Guidelines for Diagnosis, Treatment, Prevention and Control. Geneva: World Health Organization (2009). p. $10-2$.

77. Deen JL, Harris E, Wills B, Balmaseda A, Hammond SN, Rocha C, et al. The WHO dengue classification and case definitions: time for a reassessment. Lancet (2006) 368:170-3. doi: 10.1016/s0140-6736(06)69006-5

78. Guy B, Nougarede N, Begue S, Sanchez V, Souag N, Carre M, et al. Cell-mediated immunity induced by chimeric tetravalent dengue vaccine in naive or flavivirus-primed subjects. Vaccine (2008) 26:5712-21. doi: 10.1016/j.vaccine.2008.08.019

79. Bhatt S, Gething PW, Brady OJ, Messina JP, Farlow AW, Moyes CL, et al. The global distribution and burden of dengue. Nature (2013) 496:504-7. doi: 10.1038/nature12060

80. Munoz FM, Piedra PA, Demmler GJ. Disseminated adenovirus disease in immunocompromised and immunocompetent children. Clin Infect Dis. (1998) 27:1194-200.

81. Reyes-Andrade J, Sánchez-Céspedes J, Olbrich P, Falcon L, SanchezGanfornina I, Tebruegge M, et al. Meningoencephalitis due to adenovirus in a healthy infant mimicking severe bacterial sepsis. Pediatr Infect Dis J. (2014) 33:416-9. doi: 10.1097/inf.0000000000000128

82. Lion T, Kosulin K, Landlinger C, Rauch M, Preuner S, Jugovic D, et al. Monitoring of adenovirus load in stool by real-time PCR permits early detection of impending invasive infection in patients after allogeneic stem cell transplantation. Leukemia (2010) 24:706-14. doi: 10.1038/leu.2010.4

83. Low SY, Tan TT, Lee CH, Loo CM, Chew HC. Severe adenovirus pneumonia requiring extracorporeal membrane oxygenation support-Serotype 7 revisited. Respir Med. (2013) 107:1810-3. doi: 10.1016/j.rmed.2013. 09.008

84. Rollé A, Schepers K, Cassadou S, Curlier E, Madeux B, Hermann-Storck $\mathrm{C}$, et al. Severe sepsis and septic shock associated with chikungunya virus infection, Guadeloupe, 2014. Emerg Infect Dis. (2016) 22:891-4. doi: $10.3201 /$ eid2205.151449

85. Lee BE, Joffe AR, Vaudry W. Hantavirus pulmonary syndrome: Report of the first Canadian paediatric case. Can J Infect Dis. (1998) 9:319-21.

86. Galante O, Avni YS, Fuchs L, Ferster OA, Almog Y. Coronavirus NL63induced adult respiratory distress syndrome. Am J Respir Crit Care Med. (2016) 193:100-1. doi: 10.1164/rccm.201506-1239LE

87. Hellman J. Addressing the complications of Ebola and other viral hemorrhagic fever infections: using insights from bacterial and fungal sepsis. PLoS Pathog. (2015) 11:e1005088. doi: 10.1371/journal.ppat.1005088

88. Yun NE, Walker DH. Pathogenesis of Lassa fever. Viruses (2012) 4:2031-48. doi: $10.3390 / \mathrm{v} 4102031$

89. Fleischmann C, Thomas-Rueddel DO, Hartmann M, Hartog CS, Welte T, Heublein S, et al. Hospital incidence and mortality rates of sepsis. Dtsch Arztebl Int. (2016) 113:159-66. doi: 10.3238/arztebl.2016.0159

90. Acosta CD, Knight M. Sepsis and maternal mortality. Curr Opin Obstet Gynecol. (2013) 25:109-16. doi: 10.1097/GCO.0b013e32835 e0e82

91. Kalil AC, Opal SM. Sepsis in the severely immunocompromised patient. Curr Infect Dis Rep. (2015) 17:487. doi: 10.1007/s11908-015-0487-4

92. Reinhart K, Daniels R, Kissoon N, Machado FR, Schachter RD, Finfer S. Recognizing sepsis as a global health priority - a WHO resolution. $N$ Engl J Med. (2017) 377:414-7. doi: 10.1056/NEJMp1707170 
93. Levy O. Innate immunity of the newborn: basic mechanisms and clinical correlates. Nat Rev Immunol. (2007) 7:379-90. doi: 10.1038/nri2075

94. Maródi L. Neonatal innate immunity to infectious agents. Infect Immun. (2006) 74:1999-2006. doi: 10.1128/iai.74.4.1999-2006.2006

95. Kurt-Jones EA, Belko J, Yu C, Newburger PE, Wang J, Chan M, et al. The role of toll-like receptors in herpes simplex infection in neonates. $J$ Infect Dis. (2005) 191:746-8. doi: 10.1086/427339

96. Finberg RW, Knipe DM, Kurt-Jones EA. Herpes simplex virus and toll-like receptors. Viral Immunol. (2005) 18:457-65. doi: 10.1089/vim.2005.18.457

97. Dunkelberger JR, Song WC. Complement and its role in innate and adaptive immune responses. Cell Res. (2010) 20:34-50. doi: 10.1038/cr.2009.139

98. Izurieta HS, Thompson WW, Kramarz P, Shay DK, Davis RL, DeStefano $\mathrm{F}$, et al. Influenza and the rates of hospitalization for respiratory disease among infants and young children. N Engl J Med. (2000) 342:232-9. doi: 10.1056/nejm200001273420402

99. Nair H, Nokes DJ, Gessner BD, Dherani M, Madhi SA, Singleton RJ, et al. Global burden of acute lower respiratory infections due to respiratory syncytial virus in young children: a systematic review and meta-analysis. Lancet (2010) 375:1545-55. doi: 10.1016/s0140-6736(10)60206-1

100. Tsou TP, Tan BF, Chang HY, Chen WC, Huang YP, Lai CY, et al. Community outbreak of adenovirus, Taiwan, 2011. Emerg Infect Dis. (2012) 18:1825-32. doi: 10.3201/eid1811.120629

101. Ruth A, McCracken CE, Fortenberry JD, Hall M, Simon HK, Hebbar KB. Pediatric severe sepsis: current trends and outcomes from the Pediatric Health Information Systems database. Pediatr Crit Care Med. (2014) 15:82838. doi: $10.1097 /$ pcc.0000000000000254

102. Hussain NY, Uriel A, Mammen C, Bonington A. Disseminated herpes simplex infection during pregnancy, rare but important to recognise. Qatar Med J. (2014) 2014:61-4. doi: 10.5339/qmj.2014.11

103. Goodman ZD, Ishak KG, Sesterhenn IA. Herpes simplex hepatitis in apparently immunocompetent adults. Am J Clin Pathol. (1986) 85:694-9.

104. Escobar M, Nieto AJ, Loaiza-Osorio S, Barona JS, Rosso F. Pregnant women hospitalized with chikungunya virus infection, Colombia, 2015. Emerg Infect Dis. (2017) 23, 1777-1783 doi: 10.3201/eid2311.170480

105. Acosta CD, Harrison DA, Rowan K, Lucas DN, Kurinczuk JJ, Knight M. Maternal morbidity and mortality from severe sepsis: a national cohort study. BMJ Open (2016) 6:e012323. doi: 10.1136/bmjopen-2016-012323

106. Sauerbrei A, Wutzler P. Herpes simplex and varicella-zoster virus infections during pregnancy: current concepts of prevention, diagnosis and therapy. Part 2: Varicella-zoster virus infections. Med Microbiol Immunol (2007) 196:95-102. doi: 10.1007/s00430-006-0032-z

107. Acosta CD, Knight M, Lee HC, Kurinczuk JJ, Gould JB, Lyndon A. The continuum of maternal sepsis severity: incidence and risk factors in a population-based cohort study. PLoS ONE (2013) 8:e67175. doi: 10.1371/journal.pone.0067175

108. Al-Ostad G, Kezouh A, Spence AR, Abenhaim HA. Incidence and risk factors of sepsis mortality in labor, delivery and after birth: population-based study in the USA. J Obstet Gynaecol Res. (2015) 41:1201-6. doi: 10.1111/jog.12710

109. Mason KL, Aronoff DM. Postpartum group a Streptococcus sepsis and maternal immunology. Am J Reprod Immunol. (2012) 67:91-100. doi: 10.1111/j.1600-0897.2011.01083.x

110. Mor G, Cardenas I, Abrahams V, Guller S. Inflammation and pregnancy: the role of the immune system at the implantation site. Ann N Y Acad Sci. (2011) 1221:80-7. doi: 10.1111/j.1749-6632.2010.05938.x

111. Benster B, Wood EJ. Immunoglobulin levels in normal pregnancy and pregnancy complicated by hypertension. J Obstet Gynaecol Br Commonw. (1970) 77:518-22.

112. Mor G, Cardenas I. The immune system in pregnancy: a unique complexity. Am J Reprod Immunol. (2010) 63:425-33. doi: 10.1111/j.1600-0897.2010.00836.x

113. Nasa P, Juneja D, Singh O. Severe sepsis and septic shock in the elderly: An overview. World J Crit Care Med. (2012) 1:23-30. doi: 10.5492/wjccm.v1.i1.23

114. Angus DC, Linde-Zwirble WT, Lidicker J, Clermont G, Carcillo J, Pinsky MR. Epidemiology of severe sepsis in the United States: analysis of incidence, outcome, and associated costs of care. Crit Care Med. (2001) 29:1303-10.

115. Martín S, Pérez A, Aldecoa C. Sepsis and immunosenescence in the elderly patient: a review. Front Med. (2017) 4:20. doi: 10.3389/fmed.2017.00020
116. Casqueiro J, Alves C. Infections in patients with diabetes mellitus: a review of pathogenesis. Indian J Endocrinol Metab. (2012) 16(Suppl. 1):S27-36. doi: $10.4103 / 2230-8210.94253$

117. Montull B, Menéndez R, Torres A, Reyes S, Méndez R, Zalacaín R, et al. Predictors of severe sepsis among patients hospitalized for community-acquired pneumonia. PLoS ONE (2016) 11:e0145929. doi: 10.1371/journal.pone.0145929

118. O'Hare AM, Choi AI, Bertenthal D, Bacchetti P, Garg AX, Kaufman JS, et al. Age affects outcomes in chronic kidney disease. J Am Soc Nephrol. (2007) 18:2758-65. doi: 10.1681/asn.2007040422

119. Jarad N. Chronic obstructive pulmonary disease (COPD) and old age? Chron Respir Dis. (2011) 8:143-51. doi: 10.1177/1479972311407218

120. Wang HE, Griffin R, Judd S, Shapiro NI, Safford MM. Obesity and risk of sepsis: a population-based cohort study. Obesity (2013) 21:E762-9. doi: 10.1002/oby.20468

121. Villareal DT, Apovian CM, Kushner RF, Klein S. Obesity in older adults: technical review and position statement of the American Society for Nutrition and NAASO, The Obesity Society. Am J Clin Nutr. (2005) 82:92334. doi: 10.1093/ajen/82.5.923

122. Kato S, Chmielewski M, Honda H, Pecoits-Filho R, Matsuo S, Yuzawa Y, et al. Aspects of immune dysfunction in end-stage renal disease. Clin J Am Soc Nephrol. (2008) 3:1526-33. doi: 10.2215/cjn.00950208

123. Wenisch C, Patruta S, Daxböck F, Krause R, Hörl W. Effect of age on human neutrophil function. J Leukoc Biol. (2000) 67:40-5. doi: 10.1002/jlb.67.1.40

124. Solana R, Tarazona R, Gayoso I, Lesur O, Dupuis G, Fulop T. Innate immunosenescence: effect of aging on cells and receptors of the innate immune system in humans. Semin Immunol. (2012) 24:331-41. doi: 10.1016/j.smim.2012.04.008

125. Renshaw M, Rockwell J, Engleman C, Gewirtz A, Katz J, Sambhara S. Cutting edge: impaired Toll-like receptor expression and function in aging. J Immunol. (2002) 169:4697-701. doi: 10.4049/jimmunol.169.9.4697

126. Kogut I, Scholz JL, Cancro MP, Cambier JC. B cell maintenance and function in aging. Semin Immunol. (2012) 24:342-9. doi: 10.1016/j.smim.2012. 04.004

127. Goronzy JJ, Li G, Yu M, Weyand CM. Signaling pathways in aged T cells a reflection of $\mathrm{T}$ cell differentiation, cell senescence and host environment. Semin Immunol. (2012) 24:365-72. doi: 10.1016/j.smim.2012.04.003

128. Pfister G, Weiskopf D, Lazuardi L, Kovaiou RD, Cioca DP, Keller M, et al. Naive T cells in the elderly: are they still there? Ann N Y Acad Sci. (2006) 1067:152-7. doi: 10.1196/annals.1354.018

129. Schneider EL. Cell replication and aging: in vitro and in vivo studies. Fed Proc. (1979) 38:1857-61.

130. Rink L, Cakman I, Kirchner H. Altered cytokine production in the elderly. Mech Ageing Dev. (1998) 102:199-209.

131. Franceschi C, Campisi J. Chronic inflammation (inflammaging) and its potential contribution to age-associated diseases. J Gerontol A Biol Sci Med Sci. (2014) 69(Suppl. 1):S4-9. doi: 10.1093/gerona/glu057

132. Inoue S, Suzuki K, Komori Y, Morishita Y, Suzuki-Utsunomiya K, Hozumi $\mathrm{K}$, et al. Persistent inflammation and T cell exhaustion in severe sepsis in the elderly. Crit Care (2014) 18:R130. doi: 10.1186/cc13941

133. Kale SS, Yende S. Effects of aging on inflammation and hemostasis through the continuum of critical illness. Aging Dis. (2011) 2:501-11.

134. Fishman JA. Infection in solid-organ transplant recipients. $N$ Engl J Med. (2007) 357:2601-14. doi: 10.1056/NEJMra064928

135. Schuster MG, Cleveland AA, Dubberke ER, Kauffman CA, Avery RK, Husain $\mathrm{S}$, et al. Infections in hematopoietic cell transplant recipients: results from the Organ Transplant Infection Project, a multicenter, prospective, cohort study. Open Forum Infect Dis. (2017) 4:ofx050. doi: 10.1093/ofid/ofx050

136. Gea-Banacloche JC, Opal SM, Jorgensen J, Carcillo JA, Sepkowitz KA, Cordonnier C. Sepsis associated with immunosuppressive medications: an evidence-based review. Crit Care Med (2004) 32(11 Suppl.):S578-90. doi: 10.1097/01.CCM.0000143020.27340.FF

137. Centers for Disease Control and Prevention, Infectious Disease Society of America, American Society of Blood and Marrow Transplantation. Guidelines for preventing opportunistic infections among hematopoietic stem cell transplant recipients. MMWR Recomm Rep. (2000) 49:1-128.

138. Marodi L, Casanova JL. Primary immunodeficiency diseases: the J Project. Lancet (2009) 373:2179-81. doi: 10.1016/s0140-6736(09)61171-5 
139. Bousfiha AA, Jeddane L, Ailal F, Benhsaien I, Mahlaoui N, Casanova JL, et al. Primary immunodeficiency diseases worldwide: more common than generally thought. J Clin Immunol. (2013) 33:1-7. doi: 10.1007/s10875-012-9751-7

140. Sancho-Shimizu V, Perez de Diego R, Jouanguy E, Zhang SY, Casanova JL. Inborn errors of anti-viral interferon immunity in humans. Curr Opin Virol. (2011) 1:487-96. doi: 10.1016/j.coviro.2011.10.016

141. Dupuis S, Jouanguy E, Al-Hajjar S, Fieschi C, Al-Mohsen IZ, Al-Jumaah S, et al. Impaired response to interferon-alpha/beta and lethal viral disease in human STAT1 deficiency. Nat Genet. (2003) 33:388-91. doi: 10.1038/ng1097

142. Picard C, Casanova JL, Puel A. Infectious diseases in patients with IRAK4, MyD88, NEMO, or IкB $\alpha$ deficiency. Clin Microbiol Rev. (2011) 24:490-7. doi: $10.1128 / \mathrm{cmr} .00001-11$

143. Ciancanelli MJ, Huang SX, Luthra P, Garner H, Itan Y, Volpi S, et al. Infectious disease. Life-threatening influenza and impaired interferon amplification in human IRF7 deficiency. Science (2015) 348:448-53. doi: 10.1126/science.aaa1578

144. Allen EK, Randolph AG, Bhangale T, Dogra P, Ohlson M, Oshansky CM, et al. SNP-mediated disruption of CTCF binding at the IFITM3 promoter is associated with risk of severe influenza in humans. Nat Med. (2017) 23:975-83. doi: 10.1038/nm.4370

145. Asgari S, Schlapbach LJ, Anchisi S, Hammer C, Bartha I, Junier T, et al. Severe viral respiratory infections in children with. Proc Natl Acad Sci USA. (2017) 114:8342-7. doi: 10.1073/pnas.1704259114

146. Fischer A, Notarangelo LD, Neven B, Cavazzana M, Puck JM. Severe combined immunodeficiencies and related disorders. Nat Rev Dis Primers (2015) 1:15061. doi: 10.1038/nrdp.2015.61

147. Hierholzer JC. Adenoviruses in the immunocompromised host. Clin Microbiol Rev (1992) 5:262-74.

148. Takeuchi O, Akira S. Pattern recognition receptors and inflammation. Cell (2010) 140:805-20. doi: 10.1016/j.cell.2010.01.022

149. Kurt-Jones EA, Orzalli MH, Knipe DM. Innate immune mechanisms and herpes simplex virus infection and disease. Adv Anat Embryol Cell Biol. (2017) 223:49-75. doi: 10.1007/978-3-319-53168-7_3

150. Katze MG, He Y, Gale M. Viruses and interferon: a fight for supremacy. Nat Rev Immunol. (2002) 2:675-87. doi: 10.1038/nri888

151. Akira S, Uematsu S, Takeuchi O. Pathogen recognition and innate immunity. Cell (2006) 124:783-801. doi: 10.1016/j.cell.2006.02.015

152. Iwasaki A, Medzhitov R. Toll-like receptor control of the adaptive immune responses. Nat Immunol. (2004) 5:987-95. doi: 10.1038/ni1112

153. Murphy AA, Rosato PC, Parker ZM, Khalenkov A, Leib DA. Synergistic control of herpes simplex virus pathogenesis by IRF-3, and IRF-7 revealed through non-invasive bioluminescence imaging. Virology (2013) 444:71-9. doi: 10.1016/j.virol.2013.05.034

154. Marchant A, Devière J, Byl B, De Groote D, Vincent JL, Goldman M. Interleukin-10 production during septicaemia. Lancet (1994) 343:707-8.

155. Wiersinga WJ, Leopold SJ, Cranendonk DR, van der Poll T. Host innate immune responses to sepsis. Virulence (2014) 5:36-44. doi: 10.4161/viru.25436

156. Sato A, Linehan MM, Iwasaki A. Dual recognition of herpes simplex viruses by TLR2 and TLR9 in dendritic cells. Proc Natl Acad Sci USA. (2006) 103:17343-8. doi: 10.1073/pnas.0605102103

157. Bociaga-Jasik M, Cieśla A, Kalinowska-Nowak A, Skwara P, Garlicki A, Mach T. Role of IL- 6 and neopterin in the pathogenesis of herpetic encephalitis. Pharmacol Rep. (2011) 63:1203-9. doi: 10.1016/S1734-1140(11)70640-5

158. Nagamori T, Koyano S, Asai Y, Nohara F, Okamoto T, Nagaya K, et al. Sequential changes in pathophysiology of systemic inflammatory response in a disseminated neonatal herpes simplex virus (HSV) infection. J Clin Virol. (2012) 53:265-7. doi: 10.1016/j.jcv.2011.12.017

159. Hotchkiss RS, Swanson PE, Freeman BD, Tinsley KW, Cobb JP, Matuschak GM, et al. Apoptotic cell death in patients with sepsis, shock, and multiple organ dysfunction. Crit Care Med. (1999) 27:1230-51.

160. Richer MJ, Lavallée DJ, Shanina I, Horwitz MS. Toll-like receptor 3 signaling on macrophages is required for survival following coxsackievirus B4 infection. PLoS ONE (2009) 4:e4127. doi: 10.1371/journal.pone.00 04127

161. Coyne CB, Bozym R, Morosky SA, Hanna SL, Mukherjee A, Tudor M, et al. Comparative RNAi screening reveals host factors involved in enterovirus infection of polarized endothelial monolayers. Cell Host Microbe (2011) 9:70-82. doi: 10.1016/j.chom.2011.01.001

162. Triantafilou K, Orthopoulos G, Vakakis E, Ahmed MA, Golenbock DT, Lepper PM, et al. Human cardiac inflammatory responses triggered by coxsackie B viruses are mainly Toll-like receptor (TLR) 8-dependent. Cell Microbiol. (2005) 7:1117-26. doi: 10.1111/j.1462-5822.2005.00537.x

163. Hsiao HB, Chou AH, Lin SI, Chen IH, Lien SP, Liu CC, et al. Tolllike receptor 9-mediated protection of enterovirus 71 infection in mice is due to the release of danger-associated molecular patterns. J Virol. (2014) 88:11658-70. doi: 10.1128/jvi.00867-14

164. Kato H, Takeuchi O, Sato S, Yoneyama M, Yamamoto M, Matsui $\mathrm{K}$, et al. Differential roles of MDA5 and RIG-I helicases in the recognition of RNA viruses. Nature (2006) 441:101-5. doi: 10.1038/nature 04734

165. Abe Y, Fujii K, Nagata N, Takeuchi O, Akira S, Oshiumi H, et al. The toll-like receptor 3-mediated antiviral response is important for protection against poliovirus infection in poliovirus receptor transgenic mice. J Virol. (2012) 86:185-94. doi: 10.1128/jvi.05245-11

166. Barral PM, Morrison JM, Drahos J, Gupta P, Sarkar D, Fisher PB, et al. MDA-5 is cleaved in poliovirus-infected cells. J Virol. (2007) 81:3677-84. doi: 10.1128/jvi.01360-06

167. Wang B, Xi X, Lei X, Zhang X, Cui S, Wang J, et al. Enterovirus 71 protease 2Apro targets MAVS to inhibit anti-viral type I interferon responses. PLoS Pathog. (2013) 9:e1003231. doi: 10.1371/journal.ppat.1003231

168. Liu ML, Lee YP, Wang YF, Lei HY, Liu CC, Wang SM, et al. Type I interferons protect mice against enterovirus 71 infection. J Gen Virol (2005) 86(Pt 12):3263-9. doi: 10.1099/vir.0.81195-0

169. Cohen CJ, Shieh JT, Pickles RJ, Okegawa T, Hsieh JT, Bergelson JM. The coxsackievirus and adenovirus receptor is a transmembrane component of the tight junction. Proc Natl Acad Sci USA. (2001) 98:15191-6. doi: 10.1073/pnas.261452898

170. Shieh JT, Bergelson JM. Interaction with decay-accelerating factor facilitates coxsackievirus B infection of polarized epithelial cells. J Virol. (2002) 76:9474-80. doi: 10.1128/JVI.76.18.9474-9480.2002

171. Sun X, Funk CD, Deng C, Sahu A, Lambris JD, Song WC. Role of decayaccelerating factor in regulating complement activation on the erythrocyte surface as revealed by gene targeting. Proc Natl Acad Sci USA. (1999) 96:628-33.

172. Excoffon KJ, Gansemer N, Traver G, Zabner J. Functional effects of coxsackievirus and adenovirus receptor glycosylation on homophilic adhesion and adenoviral infection. J Virol. (2007) 81:5573-8. doi: 10.1128/jvi.02562-06

173. Shieh J, Stanley M, Schapiro J, Lorey T. Comparison of the GenMark eSensor respiratory viral panel to routine respiratory culture on R-Mix cells. J Mol Diagn. (2012) 14:671-2. doi: 10.1016/S1525-1578(12)00211-5

174. Ylipaasto P, Smura T, Gopalacharyulu P, Paananen A, Seppänen-Laakso T, Kaijalainen S, et al. Enterovirus-induced gene expression profile is critical for human pancreatic islet destruction. Diabetologia (2012) 55:3273-83. doi: $10.1007 / \mathrm{s} 00125-012-2713-\mathrm{z}$

175. Fortuna D, Cárdenas AM, Graf EH, Harshyne LA, Hooper DC, Prosniak $\mathrm{M}$, et al. Human parechovirus and enterovirus initiate distinct CNS innate immune responses: Pathogenic and diagnostic implications. J Clin Virol. (2017) 86:39-45. doi: 10.1016/j.jcv.2016.11.007

176. Triantafilou K, Vakakis E, Orthopoulos G, Ahmed MA, Schumann C, Lepper PM, et al. TLR8 and TLR7 are involved in the host's immune response to human parechovirus 1. Eur J Immunol. (2005) 35:2416-23. doi: 10.1002/eji.200526149

177. Uematsu S, Akira S. Toll-like receptors and type I interferons. J Biol Chem. (2007) 282:15319-23. doi: 10.1074/jbc.R700009200

178. Chang JT, Yang CS, Chen YS, Chen BC, Chiang AJ, Chang YH, et al. Genome and infection characteristics of human parechovirus type 1: the interplay between viral infection and type I interferon antiviral system. PLOS ONE (2015) 10:e0116158. doi: 10.1371/journal.pone.0116158

179. Harvala H, Wolthers KC, Simmonds P. Parechoviruses in children: understanding a new infection. Curr Opin Infect Dis. (2010) 23:224-30. doi: 10.1097/QCO.0b013e32833890ca

180. Westerhuis BM, Koen G, Wildenbeest JG, Pajkrt D, de Jong MD, Benschop $\mathrm{KS}$, et al. Specific cell tropism and neutralization of human parechovirus 
types 1 and 3: implications for pathogenesis and therapy development. J Gen Virol. (2012) 93(Pt 11):2363-70. doi: 10.1099/vir.0.043323-0

181. Guillot L, Le Goffic R, Bloch S, Escriou N, Akira S, Chignard M, et al. Involvement of toll-like receptor 3 in the immune response of lung epithelial cells to double-stranded RNA and influenza A virus. J Biol Chem. (2005) 280:5571-80. doi: 10.1074/jbc.M410592200

182. Imai Y, Kuba K, Neely GG, Yaghubian-Malhami R, Perkmann T, van Loo G, et al. Identification of oxidative stress and Toll-like receptor 4 signaling as a key pathway of acute lung injury. Cell (2008) 133:235-49. doi: 10.1016/j.cell.2008.02.043

183. Diebold SS, Kaisho T, Hemmi H, Akira S, Reis e Sousa C. Innate antiviral responses by means of TLR7-mediated recognition of single-stranded RNA. Science (2004) 303:1529-31. doi: 10.1126/science.1093616

184. Pichlmair A, Schulz O, Tan CP, Näslund TI, Liljeström P, Weber F, et al. RIG-I-mediated antiviral responses to single-stranded RNA bearing $5^{\prime}$-phosphates. Science (2006) 314:997-1001. doi: 10.1126/science. 1132998

185. Kawai T, Akira S. Toll-like receptor and RIG-I-like receptor signaling. Ann N Y Acad Sci. (2008) 1143:1-20. doi: 10.1196/annals.1443.020

186. Esposito S, Molteni CG, Giliani S, Mazza C, Scala A, Tagliaferri L, et al. Toll-like receptor 3 gene polymorphisms and severity of pandemic A/H1N1/2009 influenza in otherwise healthy children. Virol J. (2012) 9:270. doi: $10.1186 / 1743-422 x-9-270$

187. Matthay MA, Zemans RL. The acute respiratory distress syndrome: pathogenesis and treatment. Annu Rev Pathol. (2011) 6:147-63. doi: 10.1146/annurev-pathol-011110-130158

188. Takizawa T, Ohashi K, Nakanishi Y. Possible involvement of double-stranded RNA-activated protein kinase in cell death by influenza virus infection. J Virol. (1996) 70:8128-32.

189. Berthiaume Y, Matthay MA. Alveolar edema fluid clearance and acute lung injury. Respir Physiol Neurobiol. (2007) 159:350-9. doi: 10.1016/j.resp.2007.05.010

190. Mullin JM, Snock KV. Effect of tumor necrosis factor on epithelial tight junctions and transepithelial permeability. Cancer Res. (1990) 50:2172-6.

191. Weiland JE, Davis WB, Holter JF, Mohammed JR, Dorinsky PM, Gadek JE. Lung neutrophils in the adult respiratory distress syndrome. Clinical and pathophysiologic significance. Am Rev Respir Dis. (1986) 133:218-25. doi: 10.1164/arrd.1986.133.2.218

192. Högner K, Wolff T, Pleschka S, Plog S, Gruber AD, Kalinke U, et al. Macrophage-expressed IFN- $\beta$ contributes to apoptotic alveolar epithelial cell injury in severe influenza virus pneumonia. PLoS Pathog. (2013) 9:e1003188. doi: 10.1371/journal.ppat.1003188

193. Tsai YT, Chang SY, Lee CN, Kao CL. Human TLR3 recognizes dengue virus and modulates viral replication in vitro. Cell Microbiol. (2009) 11:604-15. doi: 10.1111/j.1462-5822.2008.01277.x

194. Urcuqui-Inchima S, Cabrera J, Haenni AL. Interplay between dengue virus and Toll-like receptors, RIG-I/MDA5 and microRNAs: Implications for pathogenesis. Antiviral Res. (2017) 147:47-57. doi: 10.1016/j.antiviral.2017.09.017

195. Olagnier D, Scholte FE, Chiang C, Albulescu IC, Nichols C, He Z, et al. Inhibition of dengue and chikungunya virus infections by RIG-I-mediated type I interferon-independent stimulation of the innate antiviral response. $J$ Virol. (2014) 88:4180-94. doi: 10.1128/jvi.03114-13

196. Nasirudeen AM, Wong HH, Thien P, Xu S, Lam KP, Liu DX. RIG-I, MDA5 and TLR3 synergistically play an important role in restriction of dengue virus infection. PLoS Negl Trop Dis. (2011) 5:e926. doi: 10.1371/journal.pntd.0000926

197. Azeredo EL, Neves-Souza PC, Alvarenga AR, Reis SR, Torrentes-Carvalho A, Zagne SM, et al. Differential regulation of toll-like receptor-2, tolllike receptor-4, CD16 and human leucocyte antigen-DR on peripheral blood monocytes during mild and severe dengue fever. Immunology (2010) 130:202-16. doi: 10.1111/j.1365-2567.2009.03224.x

198. Diamond MS. Evasion of innate and adaptive immunity by flaviviruses. Immunol Cell Biol. (2003) 81:196-206. doi: 10.1046/j.1440-1711.2003.01157.x

199. Castillo Ramirez JA, Urcuqui-Inchima S. Dengue virus control of type I IFN responses: a history of manipulation and control. J Interferon Cytokine Res. (2015) 35:421-30. doi: 10.1089/jir.2014.0129
200. Costa VV, Fagundes CT, Souza DG, Teixeira MM. Inflammatory and innate immune responses in dengue infection: protection versus disease induction. Am J Pathol. (2013) 182:1950-61. doi: 10.1016/j.ajpath.2013.02.027

201. Davenport EE, Burnham KL, Radhakrishnan J, Humburg P, Hutton P, Mills TC, et al. Genomic landscape of the individual host response and outcomes in sepsis: a prospective cohort study. Lancet Respir Med. (2016) 4:259-71. doi: 10.1016/s2213-2600(16)00046-1

202. Wong HR, Cvijanovich NZ, Anas N, Allen GL, Thomas NJ, Bigham MT, et al. Developing a clinically feasible personalized medicine approach to pediatric septic shock. Am J Respir Crit Care Med. (2015) 191:309-15. doi: 10.1164/rccm.201410-1864OC

203. Daviaud F, Grimaldi D, Dechartres A, Charpentier J, Geri G, Marin N, et al. Timing and causes of death in septic shock. Ann Intensive Care (2015) 5:16. doi: 10.1186/s13613-015-0058-8

204. Weiss SL, Balamuth F, Hensley J, Fitzgerald JC, Bush J, Nadkarni VM, et al. The Epidemiology of Hospital Death following pediatric severe sepsis: when, why, and how children with sepsis die. Pediatr Crit Care Med. (2017) 18:823-30. doi: 10.1097/PCC.0000000000001222

205. Cvetkovic M, Lutman D, Ramnarayan P, Pathan N, Inwald DP, Peters MJ. Timing of death in children referred for intensive care with severe sepsis: implications for interventional studies. Pediatr Crit Care Med. (2015) 16:410-7. doi: 10.1097/PCC.00000000000 00385

206. van der Poll T, van de Veerdonk FL, Scicluna BP, Netea MG. The immunopathology of sepsis and potential therapeutic targets. Nat Rev Immunol. (2017) 17:407-20. doi: 10.1038/nri.2017.36

207. Hotchkiss RS, Monneret G, Payen D. Sepsis-induced immunosuppression: from cellular dysfunctions to immunotherapy. Nat Rev Immunol. (2013) 13:862-74. doi: 10.1038/nri3552

208. Luyt CE, Combes A, Deback C, Aubriot-Lorton MH, Nieszkowska A, Trouillet JL, et al. Herpes simplex virus lung infection in patients undergoing prolonged mechanical ventilation. Am J Respir Crit Care Med. (2007) 175:935-42. doi: 10.1164/rccm.200609-1322OC

209. Limaye AP, Kirby KA, Rubenfeld GD, Leisenring WM, Bulger EM, Neff $\mathrm{MJ}$, et al. Cytomegalovirus reactivation in critically ill immunocompetent patients. JAMA (2008) 300:413-22. doi: 10.1001/jama.300.4.413

210. Borrow P, Evans CF, Oldstone MB. Virus-induced immunosuppression: immune system-mediated destruction of virus-infected dendritic cells results in generalized immune suppression. J Virol. (1995) 69:1059-70.

211. Kahan SM, Wherry EJ, Zajac AJ. T cell exhaustion during persistent viral infections. Virology (2015) 479-480:180-93. doi: 10.1016/j.virol.2014.12.033

212. Hwang JY, Jun EJ, Seo I, Won M, Ahn J, Kim YK, et al. Characterization of infections of human leukocytes by non-polio enteroviruses. Intervirology (2012) 55:333-41. doi: 10.1159/000329987

213. Wherry EJ, Day CL, Draenert R, Miller JD, Kiepiela P, Woodberry T, et al. HIV-specific CD8 T cells express low levels of IL-7Ralpha: implications for HIV-specific T cell memory. Virology (2006) 353:366-73. doi: 10.1016/j.virol.2006.06.017

214. Wherry EJ, Ahmed R. Memory CD8 T-cell differentiation during viral infection. J Virol. (2004) 78:5535-45. doi: 10.1128/jvi.78.11.5535-5545.2004

215. Fuller MJ, Khanolkar A, Tebo AE, Zajac AJ. Maintenance, loss, and resurgence of $\mathrm{T}$ cell responses during acute, protracted, and chronic viral infections. J Immunol. (2004) 172:4204-14.

216. Gallimore A, Glithero A, Godkin A, Tissot AC, Plückthun A, Elliott T, et al. Induction and exhaustion of lymphocytic choriomeningitis virusspecific cytotoxic $\mathrm{T}$ lymphocytes visualized using soluble tetrameric major histocompatibility complex class I-peptide complexes. J Exp Med. (1998) 187:1383-93. doi: 10.4049/jimmunol.172.7.4204

217. Wherry EJ, Blattman JN, Murali-Krishna K, van der Most R, Ahmed R. Viral persistence alters CD8 T-cell immunodominance and tissue distribution and results in distinct stages of functional impairment. J Virol. (2003) 77:4911-27. doi: 10.1128/JVI.77.8.4911-4927.2003

218. Zajac AJ, Blattman JN, Murali-Krishna K, Sourdive DJ, Suresh M, Altman JD, et al. Viral immune evasion due to persistence of activated T cells without effector function. J Exp Med. (1998) 188:2205-13.

219. Boni C, Fisicaro P, Valdatta C, Amadei B, Di Vincenzo P, Giuberti T, et al. Characterization of hepatitis B virus (HBV)-specific T-cell dysfunction in chronic HBV infection. J Virol. (2007) 81:4215-25. doi: 10.1128/jvi.02844-06 
220. El-Far M, Halwani R, Said E, Trautmann L, Doroudchi M, Janbazian L, et al. T-cell exhaustion in HIV infection. Curr HIV/AIDS Rep. (2008) 5:13-9. doi: 10.1007/s11904-008-0003-7

221. Radziewicz H, Ibegbu CC, Fernandez ML, Workowski KA, Obideen K, Wehbi M, et al. Liver-infiltrating lymphocytes in chronic human hepatitis C virus infection display an exhausted phenotype with high levels of PD-1 and low levels of CD127 expression. J Virol. (2007) 81:2545-53. doi: 10.1128/jvi.02021-06

222. Appay V, van Lier RA, Sallusto F, Roederer M. Phenotype and function of human T lymphocyte subsets: consensus and issues. Cytometry A (2008) 73:975-83. doi: 10.1002/cyto.a.20643

223. Appay V, Dunbar PR, Callan M, Klenerman P, Gillespie GM, Papagno $\mathrm{L}$, et al. Memory CD8+ $\mathrm{T}$ cells vary in differentiation phenotype in different persistent virus infections. Nat Med. (2002) 8:379-85. doi: 10.1038/nm0402-379

224. Tussey LG, Nair US, Bachinsky M, Edwards BH, Bakari J, Grimm K, et al. Antigen burden is major determinant of human immunodeficiency virusspecific CD8+ T cell maturation state: potential implications for therapeutic immunization. J Infect Dis. (2003) 187:364-74. doi: 10.1086/367707

225. Griffin DE. Measles virus-induced suppression of immune responses. Immunol Rev. (2010) 236:176-89. doi: 10.1111/j.1600-065X.2010.00925.x

226. Sidorenko SP, Clark EA. The dual-function CD150 receptor subfamily: the viral attraction. Nat Immunol. (2003) 4:19-24. doi: 10.1038/ni0103-19

227. Hirsch RL, Griffin DE, Johnson RT, Cooper SJ, Lindo de Soriano I, Roedenbeck $S$, et al. Cellular immune responses during complicated and uncomplicated measles virus infections of man. Clin Immunol Immunopathol. (1984) 31:1-12.

228. Mina MJ, Metcalf CJ, de Swart RL, Osterhaus AD, Grenfell BT. Long-term measles-induced immunomodulation increases overall childhood infectious disease mortality. Science (2015) 348:694-9. doi: 10.1126/science.aaa3662

229. de Vries RD, McQuaid S, van Amerongen G, Yüksel S, Verburgh RJ, Osterhaus $\mathrm{AD}$, et al. Measles immune suppression: lessons from the macaque model. PLoS Pathog. (2012) 8:e1002885. doi: 10.1371/journal.ppat.1002885

230. Schlender J, Schnorr JJ, Spielhoffer P, Cathomen T, Cattaneo R, Billeter MA, et al. Interaction of measles virus glycoproteins with the surface of uninfected peripheral blood lymphocytes induces immunosuppression in vitro. Proc Natl Acad Sci USA. (1996) 93:13194-9.

231. Grinde B. Herpesviruses: latency and reactivation - viral strategies and host response. J Oral Microbiol. (2013) 5:22766 doi: 10.3402/jom.v5i0.22766

232. Bate SL, Dollard SC, Cannon MJ. Cytomegalovirus seroprevalence in the United States: the national health and nutrition examination surveys, 19882004. Clin Infect Dis. (2010) 50:1439-47. doi: 10.1086/652438

233. Dowd JB, Palermo T, Brite J, McDade TW, Aiello A. Seroprevalence of Epstein-Barr virus infection in U.S. children ages 6-19, 2003-2010. PLoS ONE (2013) 8:e64921. doi: 10.1371/journal.pone.0064921

234. Bradley H, Markowitz LE, Gibson T, McQuillan GM. Seroprevalence of herpes simplex virus types 1 and 2-United States, 1999-2010. J Infect Dis. (2014) 209:325-33. doi: 10.1093/infdis/jit458

235. Walton AH, Muenzer JT, Rasche D, Boomer JS, Sato B, Brownstein BH, et al. Reactivation of multiple viruses in patients with sepsis. PLoS ONE (2014) 9:e98819. doi: 10.1371/journal.pone.0098819

236. Kalil AC, Florescu DF. Prevalence and mortality associated with cytomegalovirus infection in nonimmunosuppressed patients in the intensive care unit. Crit Care Med. (2009) 37:2350-8. doi: 10.1097/CCM.0b013e3181a3aa43

237. Ong DSY, Bonten MJM, Spitoni C, Verduyn Lunel FM, Frencken JF, Horn J, et al. Epidemiology of multiple herpes viremia in previously immunocompetent patients with septic shock. Clin Infect Dis. (2017) 64:1204-10. doi: 10.1093/cid/cix120

238. Tomino A, Tsuda M, Aoki R, Kajita Y, Hashiba M, Terajima T, et al. Increased PD-1 expression and altered $\mathrm{T}$ cell repertoire diversity predict mortality in patients with septic shock: a preliminary study. PLoS ONE (2017) 12:e0169653. doi: 10.1371/journal.pone.0169653

239. Miles DJ, Sanneh M, Holder B, Crozier S, Nyamweya S, Touray ES, et al. Cytomegalovirus infection induces T-cell differentiation without impairing antigen-specific responses in Gambian infants. Immunology (2008) 124:388400. doi: $10.1111 / \mathrm{j} .1365-2567.2007 .02787 . \mathrm{x}$
240. Miles DJ, van der Sande M, Jeffries D, Kaye S, Ismaili J, Ojuola O, et al. Cytomegalovirus infection in Gambian infants leads to profound CD8 T-cell differentiation. J Virol. (2007) 81:5766-76. doi: 10.1128/jvi.00 052-07

241. Holder B, Miles DJ, Kaye S, Crozier S, Mohammed NI, Duah NO, et al. Epstein-Barr virus but not cytomegalovirus is associated with reduced vaccine antibody responses in Gambian infants. PLoS ONE (2010) 5:e14013. doi: 10.1371/journal.pone.0014013

242. Cook $\mathrm{CH}$, Trgovcich J. Cytomegalovirus reactivation in critically ill immunocompetent hosts: a decade of progress and remaining challenges. Antiviral Res. (2011) 90:151-9. doi: 10.1016/j.antiviral.2011.03.179

243. Cook CH, Martin LC, Yenchar JK, Lahm MC, McGuinness B, Davies EA, et al. Occult herpes family viral infections are endemic in critically ill surgical patients. Crit Care Med. (2003) 31:1923-9. doi: 10.1097/01.Ccm.0000070222.11325.C4

244. Sweeney TE, Wong HR, Khatri P. Robust classification of bacterial and viral infections via integrated host gene expression diagnostics. Sci Transl Med. (2016) 8:346ra91. doi: 10.1126/scitranslmed.aaf7165

245. Sampson DL, Fox BA, Yager TD, Bhide S, Cermelli S, McHugh LC, et al. A four-biomarker blood signature discriminates systemic inflammation due to viral infection versus other etiologies. Sci Rep. (2017) 7:2914. doi: $10.1038 / s 41598-017-02325-8$

246. Bhattacharya S, Rosenberg AF, Peterson DR, Grzesik K, Baran AM, Ashton JM, et al. Transcriptomic biomarkers to discriminate bacterial from nonbacterial infection in adults hospitalized with respiratory illness. Sci Rep. (2017) 7:6548. doi: 10.1038/s41598-017-06738-3

247. Kumar A, Roberts D, Wood KE, Light B, Parrillo JE, Sharma S, et al. Duration of hypotension before initiation of effective antimicrobial therapy is the critical determinant of survival in human septic shock. Crit Care Med. (2006) 34:1589-96. doi: 10.1097/01.Ccm.0000217961.75225.E9

248. Abzug MJ, Michaels MG, Wald E, Jacobs RF, Romero JR, Sánchez PJ, et al. A randomized, double-blind, placebo-controlled trial of pleconaril for the treatment of neonates with enterovirus sepsis. J Pediatric Infect Dis Soc. (2016) 5:53-62. doi: 10.1093/jpids/piv015

249. Nilsen AE, Aasen T, Halsos AM, Kinge BR, Tjotta EA, Wikstrom K, et al. Efficacy of oral acyclovir in the treatment of initial and recurrent genital herpes. Lancet (1982) 2:571-3.

250. De Clercq E, Li G. Approved antiviral drugs over the past 50 years. Clin Microbiol Rev. (2016) 29:695-747. doi: 10.1128/cmr.00102-15

251. Kawai N, Ikematsu H, Hirotsu N, Maeda T, Kawashima T, Tanaka O, et al. Clinical effectiveness of oseltamivir and zanamivir for treatment of influenza A virus subtype H1N1 with the H274Y mutation: a Japanese, multicenter study of the 2007-2008 and 2008-2009 influenza seasons. Clin Infect Dis. (2009) 49:1828-35. doi: 10.1086/648424

252. Limaye AP, Stapleton RD, Peng L, Gunn SR, Kimball LE, Hyzy R, et al. Effect of ganciclovir on IL-6 levels among cytomegalovirus-seropositive adults with critical illness: a randomized clinical trial. JAMA (2017) 318:731-40. doi: 10.1001/jama.2017.10569

253. Razonable RR. Antiviral drugs for viruses other than human immunodeficiency virus. Mayo Clin Proc. (2011) 86:1009-26. doi: $10.4065 / \mathrm{mcp} .2011 .0309$

254. Vincent JL, Sun Q, Dubois MJ. Clinical trials of immunomodulatory therapies in severe sepsis and septic shock. Clin Infect Dis. (2002) 34:1084-93. doi: $10.1086 / 339549$

255. Abraham E, Wunderink R, Silverman H, Perl TM, Nasraway S, Levy H, et al. Efficacy and safety of monoclonal antibody to human tumor necrosis factor alpha in patients with sepsis syndrome. A randomized, controlled, doubleblind, multicenter clinical trial. TNF-alpha MAb Sepsis Study Group. JAMA (1995) 273:934-41.

256. Annane D, Bellissant E, Bollaert PE, Briegel J, Keh D, Kupfer Y. Corticosteroids for treating sepsis. Cochrane Database Syst Rev. (2015) (12):CD002243. doi: 10.1002/14651858.CD002243.pub3

257. Abraham E. Why immunomodulatory therapies have not worked in sepsis. Intensive Care Med. (1999) 25:556-66.

258. Zhang F, Kramer CV. Corticosteroids for dengue infection. Cochrane Database Syst Rev. (2014) CD003488. doi: 10.1002/14651858.CD003488.pub3 
259. Tam DT, Ngoc TV, Tien NT, Kieu NT, Thuy TT, Thanh LT, et al. Effects of short-course oral corticosteroid therapy in early dengue infection in Vietnamese patients: a randomized, placebo-controlled trial. Clin Infect Dis. (2012) 55:1216-24. doi: 10.1093/cid/cis655

260. Rodrigo C, Leonardi-Bee J, Nguyen-Van-Tam JS, Lim WS. Effect of corticosteroid therapy on influenza-related mortality: a systematic review and meta-analysis. J Infect Dis. (2015) 212:183-94. doi: 10.1093/infdis/jiu645

261. Cao B, Gao H, Zhou B, Deng X, Hu C, Deng C, et al. Adjuvant corticosteroid treatment in adults with influenza A (H7N9) viral pneumonia. Crit Care Med. (2016) 44:e318-28. doi: 10.1097/ccm.0000000000001616

262. Tunkel AR, Glaser CA, Bloch KC, Sejvar JJ, Marra CM, Roos KL, et al. The management of encephalitis: clinical practice guidelines by the Infectious Diseases Society of America. Clin Infect Dis. (2008) 47:303-27. doi: $10.1086 / 589747$

263. Solomon T, Michael BD, Smith PE, Sanderson F, Davies NW, Hart IJ, et al. Management of suspected viral encephalitis in adults-Association of British Neurologists and British Infection Association National Guidelines. J Infect. (2012) 64:347-73. doi: 10.1016/j.jinf.2011.11.014

264. Ramos-Estebanez C, Lizarraga KJ, Merenda A. A systematic review on the role of adjunctive corticosteroids in herpes simplex virus encephalitis: is timing critical for safety and efficacy? Antivir Ther. (2014) 19:133-9. doi: 10.3851/imp2683

265. Leentjens J, Kox M, van der Hoeven JG, Netea MG, Pickkers P. Immunotherapy for the adjunctive treatment of sepsis: from immunosuppression to immunostimulation. Time for a paradigm change? Am J Respir Crit Care Med. (2013) 187:1287-93. doi: 10.1164/rccm.201301-0036CP

266. Frenck RW, Sarman G, Harper TE, Buescher ES. The ability of recombinant murine granulocyte-macrophage colony-stimulating factor to protect neonatal rats from septic death due to Staphylococcus aureus. J Infect Dis. (1990) 162:109-14.

267. Unsinger J, Burnham CA, McDonough J, Morre M, Prakash PS, Caldwell $\mathrm{CC}$, et al. Interleukin-7 ameliorates immune dysfunction and improves survival in a 2-hit model of fungal sepsis. J Infect Dis. (2012) 206:606-16. doi: 10.1093/infdis/jis383

268. Rutigliano JA, Sharma S, Morris MY, Oguin TH, McClaren JL, Doherty $\mathrm{PC}$, et al. Highly pathological influenza A virus infection is associated with augmented expression of PD-1 by functionally compromised virusspecific CD8+ T cells. J Virol. (2014) 88:1636-51. doi: 10.1128/jvi. 02851-13

269. Rao M, Valentini D, Dodoo E, Zumla A, Maeurer M. Anti-PD-1/PD-L1 therapy for infectious diseases: learning from the cancer paradigm. Int $J$ Infect Dis. (2017) 56:221-8. doi: 10.1016/j.ijid.2017.01.028

270. Shindo Y, McDonough JS, Chang KC, Ramachandra M, Sasikumar PG, Hotchkiss RS. Anti-PD-L1 peptide improves survival in sepsis. J Surg Res. (2017) 208:33-9. doi: 10.1016/j.jss.2016.08.099

271. Liu Q, An L, Qi Z, Zhao Y, Li C. Increased expression of programmed cell death-1 in regulatory $\mathrm{T}$ cells of patients with severe sepsis and septic shock: an observational clinical study. Scand J Immunol. (2017) 86:408-17. doi: $10.1111 /$ sji.12612
272. Fedson DS. Treating the host response to emerging virus diseases: lessons learned from sepsis, pneumonia, influenza and Ebola. Ann Transl Med. (2016) 4:421. doi: 10.21037/atm.2016.11.03

273. Opal SM, van der Poll T. Endothelial barrier dysfunction in septic shock. $J$ Intern Med. (2015) 277:277-93. doi: 10.1111/joim.12331

274. Hotchkiss RS, Moldawer LL, Opal SM, Reinhart K, Turnbull IR, Vincent JL. Sepsis and septic shock. Nat Rev Dis Primers (2016) 2:16045. doi: $10.1038 /$ nrdp. 2016.45

275. Steinberg BE, Goldenberg NM, Lee WL. Do viral infections mimic bacterial sepsis? The role of microvascular permeability: a review of mechanisms and methods. Antiviral Res. (2012) 93:2-15. doi: 10.1016/j.antiviral.2011.10.019

276. Spiropoulou CF, Srikiatkhachorn A. The role of endothelial activation in dengue hemorrhagic fever and hantavirus pulmonary syndrome. Virulence (2013) 4:525-36. doi: 10.4161/viru.25569

277. Korteweg C, Gu J. Pathology, molecular biology, and pathogenesis of avian influenza A (H5N1) infection in humans. Am J Pathol. (2008) 172:1155-70. doi: 10.2353/ajpath.2008.070791

278. Su JB. Vascular endothelial dysfunction and pharmacological treatment. World J Cardiol. (2015) 7:719-41. doi: 10.4330/wjc.v7.i11.719

279. Fedson DS, Jacobson JR, Rordam OM, Opal SM. Treating the host response to Ebola virus disease with generic statins and angiotensin receptor blockers. MBio (2015) 6:e00716. doi: 10.1128/mBio.00716-15

280. Fedson DS. Statin protection against influenza and COPD mortality: response. Chest (2007) 132:1406-7. doi: 10.1378/chest.07-0992

281. Fedson DS. Statins, influenza vaccination and influenza. J Infect Dis. (2017) 215:484-5. doi: 10.1093/infdis/jiw537

282. Patel JM, Snaith C, Thickett DR, Linhartova L, Melody T, Hawkey P, et al. Randomized double-blind placebo-controlled trial of $40 \mathrm{mg} / \mathrm{day}$ of atorvastatin in reducing the severity of sepsis in ward patients (ASEPSIS Trial). Crit Care (2012) 16:R231. doi: 10.1186/cc11895

Conflict of Interest Statement: AP has previously conducted studies on behalf of Oxford University funded by vaccine manufacturers, but currently does not undertake industry funded clinical trials. AP chairs the UK Department of Health's (DH) Joint Committee on Vaccination and Immunisation (JCVI) and is a member of the World Health Organization's (WHO) Strategic Advisory Group of Experts. The views expressed in this manuscript are those of the authors and do not necessarily reflect the views of the JCVI, the DH, or the WHO.

The remaining authors declare that the research was conducted in the absence of any commercial or financial relationships that could be construed as a potential conflict of interest.

Copyright (C) 2018 Lin, McGinley, Drysdale and Pollard. This is an open-access article distributed under the terms of the Creative Commons Attribution License (CC BY). The use, distribution or reproduction in other forums is permitted, provided the original author(s) and the copyright owner(s) are credited and that the original publication in this journal is cited, in accordance with accepted academic practice. No use, distribution or reproduction is permitted which does not comply with these terms. 